\title{
Chinese perspectives on the ad bellum/in bello relationship and a cultural critique of the ad bellum/in bello separation in international humanitarian law
}

\author{
Zhuo Liang* \\ Graduate Institute of International and Development Studies, Chemin Eugène-Rigot 2, 1202 Geneva, Switzerland \\ Email: zhuo.liang@graduateinstitute.ch
}

\begin{abstract}
The intriguing relationship between jus ad bellum and jus in bello has provoked perennial academic debates. This article examines this issue from Chinese perspectives and offers a cultural critique of the well-entrenched norm of the ad bellum/in bello separation in international humanitarian law. Based on its distinctive traditional perception of the world order and the meaning of war, China embraces a holistic understanding of the ad bellum/in bello relationship. This relationship is construed as essentially harmonized. The cardinal moral principle underpinning it is that a just war should be conducted in a just way. The ad bellum/in bello separation in international humanitarian law has a Western origin, and the rationale behind it intimates Western sensitivity to the European just war tradition in which jus in bello was parasitic on jus ad bellum. It is assumed that jus ad bellum and jus in bello are irreconcilably in conflict once they come into contact with one another. This assumption is followed by a widely-held belief that any attempt to reconnect the two concepts would bring nothing but the subordination of jus in bello to jus ad bellum as experienced in European just war and, consequently, the collapse of the former. Chinese perspectives nevertheless evidence that this conventional line of thinking, hampering scholars from thinking beyond the sealed ad bellum/in bello separation, is not sound. A proposal for a more constructive solution should be taken into consideration.
\end{abstract}

Keywords: China; international humanitarian law; jus ad bellum; jus in bello; just war

\section{Introduction}

One of the common grounds shared by mainstream scholars of international humanitarian law (IHL) and military ethics is the separation between jus ad bellum - the law governing resorting to force and jus in bello - the law regulating the conduct of war. In the legal domain, the ad bellum/in bello separation has a two-fold meaning: On one hand, the legal status of the conflicting parties under jus ad bellum does not affect the application of jus in bello; on the other hand, the application of jus in bello does not alter the legality of the use of force under jus ad bellum. ${ }^{1}$ This norm is alleged to be firmly rooted in treaties, state practice, the jurisprudence of national and international courts, and the legal literature. ${ }^{2}$ In moral discourse, the ad bellum/in bello separation denotes the possibility 'for a just war to be fought unjustly and for

${ }^{\star}$ The author wishes to thank the two anonymous reviewers for their insightful comments on earlier drafts of the article. The author gratefully acknowledges the financial support from the China Scholarship Council (CSC).

${ }^{1} \mathrm{~K}$. Okimoto, The Distinction and Relationship between Jus ad Bellum and Jus in Bello (2011), 14.

${ }^{2}$ A. Bouvier, 'Assessing the Relationship between Jus in Bello and Jus ad Bellum: An “Orthodox" View', (2006) 100 Proceedings of the Annual Meeting (ASIL) 109, at 110.

(C) The Author(s), 2021. Published by Cambridge University Press. This is an Open Access article, distributed under the terms of the Creative Commons Attribution licence (http://creativecommons.org/licenses/by/4.0/), which permits unrestricted re-use, distribution, and reproduction in any medium, provided the original work is properly cited. 
an unjust war to be fought in strict accordance with the rules' ${ }^{3}$ This idea is in vogue among the majority of contemporary just war theorists and remains largely undisputed. ${ }^{4}$ Given this infrastructural character of the ad bellum/in bello separation in both IHL and ethics, occasional challenges to its legitimacy and desirability have yet, in the main, appeared to be successful. ${ }^{5}$

A keen observer may wonder about the reasons behind the mainstream's adamancy about preserving the ad bellum/in bello separation. Beyond the rationale that is commonly given for turning down the bids for revamping the relationship between the two groups of norms, there may be a critical but usually overlooked factor - the venue in which the evolution of and the pivotal debate on this norm have taken place. It may be legitimate to query whether it is the dominated tradition of IHL formed in a particular locality that necessitates such a wall of separation.

This thought echoes the increasingly intensified debate between universalism and relativism in international law. ${ }^{6}$ At first blush, modern international law - 'the only branch of law containing identical rules professedly administered as such by the courts of all nations ${ }^{7}$ - should $a b$ initio have steered clear of the relativist challenges by virtue of the inherently universal applicability of its norms. However, the universality of such a universalist perception per se seems unwarranted. As Martti Koskenniemi noted, ' $\mathrm{t}$ ] he view that there is a single, universal international law with a homogeneous history and an institutional-political project emerges from a profoundly Eurocentric view of the world'. ${ }^{8}$ In fact, the universalist claim of international law has to grapple with the everyday reality that states - the principal subject and creator of international law - vary considerably in economic regime, political ideology, traditional culture, religious belief, and legal system. It is conceivable that a rule of international law may be or may have been understood differently in different cultural contexts.

While it might be said that all civilizations have developed rules and customs aimed at restraining the brutality of war, ${ }^{9}$ the foundational IHL rules as engraved in the international legal instruments have been largely a product of the European or, in a broader sense, Western civilization. Ancient chivalric engagements, religious wars, and medieval Catholic philosophy all made up the cultural background for their creation. ${ }^{10}$ It is not a coincidence that all signatories of the Geneva Convention of 1864 were European and Christian states. ${ }^{11}$ In the negotiations of 1899 and 1907 Hague Conventions and the 1949 Geneva Conventions,

\footnotetext{
${ }^{3}$ M. Walzer, Just and Unjust Wars: A Moral Argument with Historical Illustrations (2006), 21.

${ }^{4}$ S. K. Sharma, 'Reconsidering the Jus ad Bellum/Jus in Bello Distinction', in C. Stahn and J. K. Kleffner (eds.), Jus Post Bellum: Towards a Law of Transition from Conflict to Peace (2008), 9, at 9.

${ }^{5}$ As Marko Milanovic explained, while the ad bellum/in bello separation is under constant threat, it must stand, even if it is necessary 'occasionally - but ever so carefully - to drill a hole or two through it'. See M. Milanovic, 'A Non-Response to Weiler and Deshman', (2013) 24 EJIL 63, at 65-6.

${ }^{6}$ For a succinct summary of the views of the two competing camps see A. Roberts et al., 'Conceptualizing Comparative International Law', in A. Roberts et al. (eds.), Comparative International Law (2018), 3, at 3-4.

${ }^{7}$ H. Lauterpacht, 'Decisions of Municipal Courts as a Source of International Law', (1929) 10 Brit. Y.B. Int'l L. 65 , at 95.

${ }^{8}$ M. Koskenniemi, 'The Case for Comparative International Law', (2009) 20 Finnish Y.B. Int'l L. 1, at 4.

${ }^{9}$ FForeword by Dr. Jakob Kellenberger', in J. Henckaerts and L. Doswald-Beck, Customary International Humanitarian Law (2005), vol. I, xv, at xv.

${ }^{10} \mathrm{~J}$. McMahan, 'The Ethics of Killing in War', (2006) 34 Philosophia 23, at 39.

${ }^{11}$ On 22 August 1864, the international conference at Geneva adopted the Geneva Convention for the Amelioration of the Condition of the Wounded in Armies in the Field. Representatives of the following 12 states signed the Convention: Baden, Belgium, Denmark, France, Hesse, Italy, Netherlands, Portugal, Prussia, Spain, Switzerland, and Württemberg. See D. Schindler and J. Toman (eds.), The Laws of Armed Conflicts: A Collection of Conventions, Resolutions and other Documents (2004), 367-8.
} 
non-Western participation remained far from sufficient. ${ }^{12}$ It is observed that the legal regime of IHL was strongly influenced by Western culture and European powers up until the $1970 \mathrm{~s},{ }^{13}$ not to mention the fact that the International Committee of the Red Cross (ICRC), functioning as 'the guardian of IHL' worldwide, remains a Swiss organization whose membership is open exclusively to Swiss citizens. ${ }^{14}$ Tellingly, although the concept of IHL, like that of international law, is recognized by all nations today, Western culture and values had long dominated the shaping of its fundamentals.

It can thus be presumed that the ad bellum/in bello separation as an infrastructural norm of the globally-accepted IHL is also of an indelible Western cultural imprint. Since war was historically a common occurrence for every culture and civilization, diverse regional or cultural traditions besides Europe, such as Islam, China, India, and Africa, have developed their approaches to the law of war. ${ }^{15}$ In the absence of a thorough investigation, it would be imprudent to assert that those traditions are only of historical interest. Gauging the relationship between jus ad bellum and jus in bello in non-Western fora is likely to bring out unconventional inspirations for its future evolution.

Sitting in the east end of Eurasia, China may be a worthy object of study for probing this hypothesis. China is deemed 'not just another nation-state in the family of nations' but 'a civilisation pretending to be a state'. ${ }^{16}$ As one of the world's oldest members, China has developed a distinctive cultural tradition which stands in contrast with that of others in various aspects. In the later part of the first millennium BC, China in the East and Greece and Rome in the West concurrently took the first step in human history of seeking justification for war. ${ }^{17}$ It is hence a reasonable preliminary observation that some insights might be distilled from Chinese wisdom for taming the beast of war that has beset mankind.

The pre-modern history of China is long and diverse. The earliest Chinese dynasty identified is said to be Xia, probably a preliterate and neolithic entity existing from roughly the second millennium BC. ${ }^{18}$ In the mid-fifteenth century BC, Xia was succeeded by one of its neighbours, Shang, which endured roughly for 500 years until being supplanted by the Zhou dynasty.

\footnotetext{
${ }^{12}$ For a list of delegations at the Hague Peace Conferences of 1899 and 1907 see, respectively, The Proceedings of the Hague Peace Conferences: Translation of the Official Texts: The Conference of 1899, at 2-7; The Proceedings of the Hague Peace Conferences: Translation of the Official Texts: The Conference of 1907, vol. I, at 2-15. While the second Hague Conference saw a significant growth in the Latin American participation, only China, Japan, Persia, Siam, and Turkey which attended both conferences were outside the circle of the Western and Christian civilization. For a list of delegations at the diplomatic conference for the establishment of the 1949 Geneva Conventions see Final Record of the Diplomatic Conference of Geneva of 1949, vol. I, at 158-70. Of the 63 states that participated in the drafting effort, only three African states took part, and the absence of what was not quite yet the Third World was barely noticed. See F. Mégret, 'The Universality of the Geneva Conventions', in A. Clapham, P. Gaeta and M. Sassòli (eds.), The 1949 Geneva Conventions: A Commentary (2015), 669, at 679.

${ }^{13}$ M. Sassòli, A. A. Bouvier and A. Quintin (eds.), How does Law Protect in War?: Cases, Documents and Teaching Materials on Contemporary Practice in International Humanitarian Law (2011), vol. I, Ch. 1, at 5.

${ }^{14}$ Statutes of the ICRC (adopted on 21 December 2017), Arts. 2(1), 7(1).

${ }^{15}$ See, e.g., E. G. Bello, African Customary Humanitarian Law (1980); L. Zhu, 'Traditional Asian Approaches - The Chinese View', (1980) 9 Aust. Y.B. Int'l L. 143; L. R. Penna, 'Traditional Asian Approaches: An Indian View', (1980) 9 Aust. Y.B. Int'l L. 168; A. Ndam Njoya, 'The African Concept', in International Dimensions of Humanitarian Law (1988), 5; H. Sultan, 'The Islamic Concept', in International Dimensions of Humanitarian Law (1988), 29; A. Al-Dawoody, The Islamic Law of War: Justifications and Regulations (2011); D. Liu, 'International Law and International Humanitarian Law in Ancient China', in M. Bergsmo, W. L. Cheah and P. Yi (eds.), Historical Origins of International Criminal Law (2014), vol. I, at 87; S. Rajan, 'Principles of Laws of War in Ancient India and the Concept of Mitigating Armed Conflicts through Controlled Fights', (2014) 5 Journal of International Humanitarian Legal Studies 333.

${ }^{16}$ L. W. Pye, 'China: Erratic State, Frustrated Society', (1990) 69 Foreign Affairs 56, at 58.

${ }^{17}$ S. C. Neff, War and the Law of Nations: A General History (2005), 14.

${ }^{18} \mathrm{C}$. A. Ford, The Mind of Empire: China's History and Modern Foreign Relations (2010), 19. Nevertheless, the authenticity of the existence of Xia is disputed among historians. Sceptics argued that the idea of Xia was a literary invention applied to numerous prehistoric groups and that the historical Xia never existed anywhere outside the romanticized records of later generations. See D. Boyd, 'Xia', in M. Dillon (ed.), Encyclopedia of Chinese History (2017), 764, at 764.
} 
Although nominally ruling China for the next eight centuries, the royal authority of Zhou had gone through a severe decline of power in the eighth century $\mathrm{BC}$, with its feudal states becoming de facto independent one after another. In $221 \mathrm{BC}$, the state of Qin physically unified China by conquering the rest of the warring states. A centralized bureaucracy then replaced the system of feudalism previously practiced by Zhou, marking the beginning of Imperial China (221 BC-1912). During this long period of time, new dynasties routinely emerged and replaced the old every few hundred years. Typically, Imperial China witnessed the rise and fall of the Han (206 BC-220) and Tang dynasties (618-907) which made China one of the great powers in the ancient world, the Song dynasty (960-1279) which controlled a relatively small portion of China, and the Yuan (1279-1368) and Qing dynasties (1644-1912) whose rulers were Mongols and Manchus respectively. ${ }^{19}$

Notwithstanding such an intricate storyline, the shaping of the very basis of Chinese civilization mostly took place during the Spring and Autumn and the Warring States periods (771-221 BC) prior to Qin's unification of China. Being a golden age for Chinese intellectual discourse, these splendid periods were the times when much of traditional Chinese classical literature, history, and philosophy first sprung up. ${ }^{20}$ Many great Chinese thinkers lived during these times, including Confucius, the founder of Confucianism; Mencius, honoured as the 'Second Sage' of Confucianism; Laozi, the founder of Daoism; and Mozi, the founder of Mohism. ${ }^{21}$ Since the second century BC, Confucianism, among diverse schools of thought, had been venerated as the official ideology of imperial Chinese dynasties. Chinese elites, including academicians and officers in charge, had been indoctrinated with Confucian teachings. That said, the Confucian monopolization did not obliterate the influence of other schools on Chinese civilization. A number of nonConfucian classics continued to be valued and studied in Imperial China. For example, the Seven Military Classics (武经七书), ${ }^{22}$ consisting of seven valuable treatises of the School of the Military, were compiled in the eleventh century and absorbed into the curriculum of the Chinese imperial examination system ${ }^{23}$ as a requisite for martial appointment of officials.

This article serves as both a description of Chinese perspectives on the relationship between jus ad bellum and jus in bello and a critique of the ad bellum/in bello separation in IHL from a cultural viewpoint. To lay the basis for discussion, Section 2 will introduce pre-modern China's general conception of war, including its understandings of the relationship between peace and war and the raison d'être of just war. Section 3 will zoom in on the status of jus in bello in the Chinese just war theory and explore Chinese perspectives on the relationship between jus ad bellum and jus in bello. It will also evaluate the validity of those perspectives in modern Chinese military ethics. Based on the previous findings, Section 4 will move to the cultural critique of the ad bellum/in bello separation in IHL, with the origin of and rationale for such separation surveyed in light of Chinese

\footnotetext{
${ }^{19}$ Despite the fact that during the Yuan and Qing dynasties the whole of China was ruled by ethnically non-Han peoples, Yuan and Qing still count as Chinese dynasties inasmuch as the Mongol and Manchu conquerors, being militarily victorious, adapted themselves to the Chinese tradition of running the country and did not alter the ideological continuity of Confucianism or the Chinese image of world order. See S. S. Kim, China, the United Nations and World Order (1979), 22.

${ }^{20}$ The Spring and Autumn period, in particular, witnessed a major breakthrough in the intellectual sphere, which brought Chinese culture into an 'Axial Age' of civilization and influenced all future courses of thought in China. See C. Hsu, 'The Spring and Autumn Period', in M. Loewe and E. L. Shaughnessy (eds.), The Cambridge History of Ancient China: From the Origins of Civilization to 221 B.C. (1999), 545, at 545, 583.

${ }^{21}$ For an introduction of the core tenets of the major Chinese thinkers in these periods see D. S. Nivison, 'The Classical Philosophical Writings', in Loewe and Shaughnessy, ibid, at 745.

${ }^{22}$ The Seven Military Classics comprise the following books: Six Secret Teachings (六蹈), The Methods of the Ssu-ma (司马法), The Art of War (孙子兵法), Wu-tzu (吴子), Wei Liao-tzu (尉繚子), Three Strategies of Huang Shih-kung (黄石公三略), and Questions and Replies between Tang T'ai-tsung and Li Wei-kung (唐太宗李卫公问对). The first five of them were written prior to the period of Imperial China.

${ }^{23}$ Set up in the Sui dynasty (581-618), the Chinese imperial examination system was a unique apparatus of selecting and recruiting meritocrats to serve the imperial government. It was abrogated in 1905. For an introduction of this system see R. Wang, The Chinese Imperial Examination System: An Annotated Bibliography (2013), 1-22.
} 
perspectives on the ad bellum/in bello relationship. The critique will be followed by a proposal in Section 5 for reappraising the relationship between the two bodies of legal norms.

\section{The general conception of war in pre-modern China}

Since Confucianism was the reigning ideology of Imperial China for over two millennia, the works of Confucian theorists laid the foundation for, and contributed the most to, the general conception of war, including the understanding of the ad bellum/in bello relationship, in pre-modern China. Other schools of thought, in particular the School of the Military which specialized in both the philosophy and practice of warfare, also participated in the formative process of this conception that has exerted lasting implications for modern China.

\subsection{War as a last resort to maintain or restore peace and order}

The ancient Chinese called the mortal world 'Tianxia (天下)', which literally means 'all under heaven'. ${ }^{24}$ Upon an ever-more-advanced economic and social system in the known geographical world, China devised the appellation 'Zhongguo (中国)', i.e., the 'middle kingdom' or 'central state', to dub itself with pride. It was a credo of the ancient Chinese that their country, located at the centre of Tianxia with barbarians dwelling in its margins, represented the only civilization on earth. ${ }^{25}$ At the political apex of this 'middle kingdom' sat the Chinese monarch - Tianzi (天子), 'the Son of Heaven'. Bestowed with the divine force of the Mandate of Heaven (天命), this person was designated as the nominal ruler and overseer of the entire world of humanity covering both Chinese and barbarians. ${ }^{26}$ His competence knew no limits ratione personae and ratione loci. As chanted in The Book of Poetry, '[u]nder the wide heaven, [a] 11 is the king's land; [w] ithin the sea-boundaries of the land, [a]ll are the king's servants'. ${ }^{27}$ This Sinocentric but also universalist outlook rendered the legally-fixed demarcation between China and non-Chinese states unintelligible for the ancient Chinese. As Guyuan Chen remarked, in the pre-modern Chinese concept of the world order, there was "a "nation" but no "inter"' 28

Being the centre of the world of Tianxia with a universal kingship, China was at once a comprehensive and indivisible whole - a conceptually universal empire - which envisaged no rival and also no equal. ${ }^{29}$ Accordingly, China's relation with non-Chinese peoples was distinctly hierarchical. An epitome of this hierarchy was China's methodology for differentiating between the civilized and the uncivilized. For China, the degree of civilization of a group of people was judged by neither race nor ethnicity but its cultural proximity to the 'civilized', settled, literate, and agricultural Chinese civilization. ${ }^{30}$ Based on this criterion, China distinguished among three main cultural zones: The first was the Sinic Zone which comprised the most sinicized states like Korea, Vietnam and, at brief times, Japan; the second was the Inner

\footnotetext{
${ }^{24}$ As William Callahan neatly elucidated, '[1]iterally speaking, tian is the heavens, the sky, and what is on top, while $x i a$ is an indexical term meaning below, lower, inferior. Tianxia thus refers to everything below the sky, and thus is commonly used in classical texts to refer to "the earth" and "the (Chinese) world"'. See W. A. Callahan, 'Chinese Visions of World Order: PostHegemonic or a New Hegemony?', (2008) 10 International Studies Review 749, at 751.

${ }^{25}$ J. D. Frodsham, 'Introduction', in The First Chinese Embassy to the West: The Journals of Kuo Sung-T'ao, Liu Hsi-Hung and Chang Te-Yi (1974) (translated by J. D. Frodsham), xv, at xvi.

${ }^{26} \mathrm{~T}$. Wang, 'International Law in China: Historical and Contemporary Perspectives', (1990) 221 Recueil des Cours 195, at 217.

${ }^{27}$ The Chinese Classics, Vol. IV: The She King or The Book of Poetry (诗经) (1871) (translated by J. Legge), 360.

28“陈顾远序 [Guyuan Chen in the Preface]', in J. Hong, 春秋国际公法 [International Law in the Spring and Autumn Period] (1937), 1, at 1, cited from Wang, supra note 26, at 214. China's traditional worldview made it hard for the Chinese to comprehend the multi-state system of the Western world on its first contacts with the Europeans when its isolation was definitively broken. See Wang, ibid., at 219.

${ }^{29}$ Ibid., 214.

${ }^{30} \mathrm{C}$. Holcombe, A History of East Asia: From the Origins of Civilization to the Twenty-First Century (2017), 7.
} 
Asian Zone, to which most ethically non-Han nomadic or seminomadic tribes and states belonged; and the third was the Outer Zone of the 'outer barbarians' which encompassed other states of Southeast and South Asia and Europe that were supposed to send tribute when trading with China. ${ }^{31}$ Between Chinese and non-Chinese states, no egalitarianism was ever conjured up. Such an asymmetric relation also applied between the Chinese monarch and his vassals inside the Chinese state.

In the mind of pre-modern China, peace represented the natural condition of the world of Tianxia. ${ }^{32}$ As it was natural for Tianxia to be peaceful, the legitimacy of the hierarchical and antiegalitarian Sinocentric world order rested essentially on moral edification rather than military coercion. ${ }^{33}$ It was believed that the potency of such edification derived from the virtue of the Chinese monarch. As the highest ruler of Tianxia, he was expected to turn himself into the avatar of virtuousness and benevolence, so that the less civilized, through spontaneous admiration, might voluntarily seek assimilation. ${ }^{34}$ As Confucius advocated, if neighbouring people do not submit to your ruler, then enhance your culture and virtue and draw them to you'. ${ }^{35}$ Mencius also averred that ' $[w]$ hen one has made one's own person correct, the rest of the world will follow'. ${ }^{36}$ Xunzi, another eminent Confucian philosopher, polished this idea by evincing the unnecessity of the use of force: '[A state's] laws being well ordered, its assistants worthy, its people bluntly honest, and its customs beautifully refined ... the world will submit to it without its armies exerting themselves. ${ }^{37}$ For Confucians, the ideal world was a harmonious political order without state boundaries and governed by a sage by means of virtue, without any coercive power at all. ${ }^{38}$

According to this pacifist-oriented creed, the unfortunate resort to arms was itself a sign of the failure to cultivate harmony in the world. ${ }^{39}$ It should, thus, be seen as abnormal and exceptional. Confucius was recorded to be vigilant about war. ${ }^{40} \mathrm{He}$ once highly commended Duke Huan of Qi for nine times bringing the feudal lords into assembly without employing his war chariots. ${ }^{41}$ Laozi also believed that '[o]ne who helps the lord of men according to the Way [d] oes not use arms to subdue the world'. ${ }^{42}$ The philosophical term 'Way (道)', consisting of the social methods practised by the sage kings (who were believed to be paragons of virtue), was a reflection of the ideal pattern of the moral order of the world. In a wide range of classical Chinese treatises from diverse schools of thought, weapons are portrayed as evil or inauspicious implements, and may be prudently put on the agenda only when there is no alternative means to maintain or restore the peace and order of Tianxia. ${ }^{43}$ It could be said that in traditional Chinese thought, 'war is inauspicious and to be avoided; the enemy is not necessarily

\footnotetext{
${ }^{31}$ J. K. Fairbank, 'A Preliminary Framework', in J. K. Fairbank (ed.), The Chinese World Order: Traditional China's Foreign Relations (1968), 1, at 2.

${ }^{32} \mathrm{Neff}$, supra note 17 , at 31 . In Confucianism, the end-goal of a meaningful life is to pacify the world: '[W]hen the character is cultivated, the family will be regulated; when the family is regulated, the state will be well-ordered; when the state is wellordered, the world will be pacified.' See Li ki ou Mémoires sur les bienséances et les cérémonies (礼记): texte chinois avec une double traduction en français et en latin (1913), vol. II (translated by S. Couvreur), 616, translation cited from C. Cheng, New Dimensions of Confucian and Neo-Confucian Philosophy (1991), 156.

${ }^{33} \mathrm{Z}$. Li, 'Traditional Chinese World Order', (2002) 1 Chinese J. Int'l L. 20, at 34.

${ }^{34}$ I. C. Y. Hsü, China's Entrance into the Family of Nations: The Diplomatic Phase, 1858-1880 (1968), 8.

${ }^{35}$ The Analects of Confucius (论语) (2007) (translated by B. Watson), 115, para. 1.

${ }^{36}$ Mencius (孟子) (2009) (translated by I. Bloom), 76, para. 4A4.

${ }^{37}$ Xunzi (荀子): A Translation and Study of the Complete Works (1990), vol. II (translated by J. Knoblock), 162, para. 11.8.

${ }^{38}$ D. A. Bell, Beyond Liberal Democracy: Political Thinking for an East Asian Context (2006), 24.

${ }^{39}$ J. A. Stroble, 'Justification of War in Ancient China', (1998) 8 Asian Philosophy 165, at 169.

${ }^{40}$ Watson, supra note 35 , at 49 , para. 12.

${ }^{41}$ Ibid., at 98 , para. 17.

${ }^{42}$ Daodejing (道德经) (2008) (translated by E. Ryden), 63.

${ }^{43}$ See Ryden, ibid., 65; 'T'ai Kung's Six Secret Teachings', in The Seven Military Classics of Ancient China (1993) (translated by R. D. Sawyer), 51; 'Wei Liao-tzu', in ibid., 256-7; 'Three Strategies of Huang Shih-kung', in ibid., at 306; The Annals of Lï Buwei (吕氏春秋) (2000) (translated by J. Knoblock and J. Riegel), 194, para. 8/2.4; Han Fei Zi (韩非子 (2015), vol. I (translated by W. K. Liao), 27, para. 2.3.
} 
demonized - it can be enculturated and pacified, though not exterminated or annihilated; violence is a last resort'. ${ }^{44}$

\subsection{War as punishment of the moral inferiors who committed outrages}

Despite their fundamental distaste for war, ancient Chinese thinkers admitted that war was justifiable and could be legitimately conducted if it was just. As Guanzi, a prominent politician during the Spring and Autumn period, asserted among others, 'the armed forces must be used in a righteous manner'. ${ }^{45}$ Collectively, ancient Chinese thinkers framed the Chinese theory of 'just war (义战)'.

Texts on just war widely appeared in Chinese classics. Initially, they were expected to be read and appreciated by monarchs of China or governors of the feudal states. Authors often took the war practices of the past sage kings as models to deduce rules and principles that ought to be followed. Nevertheless, those rules and principles were not legally binding norms (not even by name), but merely moral and hortatory injunctions. ${ }^{46}$ Taken as the 'foundation' or 'fundamental basis' of just war, the principle of 'benevolence and justice (仁义)' governed every and each aspect of it. ${ }^{47}$ Based on this overarching principle, Chinese thinkers, apart from requiring war to be a last resort, came up with other concrete criteria for just war.

Firstly, a just war should be initiated by a competent authority. Not all of the political entities were endowed with the competence to make a just war. Given the hierarchical relations between Chinese and non-Chinese states and between the Chinese monarch and his vassals, waging a just war was considered an exclusive power of the superior authorities. As Mencius indicated, a just war, in general, should involve superiors attacking inferiors; peers should not attack each other. ${ }^{48}$ In line with the perception that Tianxia was a universalized moral order, the competent authority to undertake a just war was not understood legally or politically, but morally. ${ }^{49}$ Such an authority should be an entity in possession of superior morality vis-à-vis usurpers, tyrants, and aggressors whose morality was inferior. ${ }^{50}$ In Mencius's words, the initiator of a punitive expedition should be 'a minister appointed by Heaven', just as only the chief judge was empowered to deprive a person of his or her life. ${ }^{51}$ Owing to its vertical texture, just war, except in the case of self-defence, was synonymous with 'punitive expeditions (征)' - wars of punishment.

In normal circumstances, the Chinese monarch, postulated to be morally superior to anyone else, was competent to wage or authorize just war. As Confucius said, '[w] hen the Way prevails in the world, rites, music, and punitive expeditions proceed from the Son of Heaven' ${ }^{52}$ Nevertheless, the Chinese monarch's de jure political status did not invariably guarantee his supremacy in

\footnotetext{
${ }^{44}$ A. I. Johnston, Cultural Realism: Strategic Culture and Grand Strategy in Chinese History (1995), 66. See also J. K. Fairbank, 'Introduction: Varieties of the Chinese Military Experience', in F. A. Kierman and J. K. Fairbank (eds.), Chinese Ways in Warfare (1974), 1, at 7; J. R. Adelman and C. Shih, Symbolic War: The Chinese Use of Force, 1840-1980 (1993), 31.

${ }^{45}$ Guanzi (管子): Political, Economic, and Philosophical Essays from Early China (2001), vol. II (translated by W. A. Rickett), 88. See also Knoblock and Riegel, supra note 43, at 199, para. 8/4.1.

${ }^{46} \mathrm{Neff}$, supra note 17 , at 34 . Confucianism despised the role of law in social governance. Ideally, the conduct of social relations should be governed by the proprieties (礼), instead of a set of rules that are backed up by state-imposed sanctions. When society was functioning peacefully and harmoniously, law was something to be avoided, because resort to law was seen as essentially an admission of the loss of virtue and failure in human and communal relations. Only when a person proved extremely recalcitrant or when the educational system failed would the use of law become necessary. See Li, supra note 33, at 40 .

${ }^{47}$ See Knoblock, supra note 37, at 228, para. 15.2; 'Wei Liao-tzu', in Sawyer, supra note 43, at 273; Editorial Board of Collected Works of Chinese Military Treatises (ed.), 中国兵书集成 [Collected Works of Chinese Military Treatises] (1992), vol. XXXXIII, at 1122-3.

${ }^{48}$ Bloom, supra note 36 , at 157 , para. $7 \mathrm{~B} 2$.

${ }^{49}$ P. Lo, 'Varieties of Statecraft and Warfare Ethics in Early China: An Overview', in P. Lo and S. B. Twiss (eds.), Chinese Just War Ethics: Origin, Development, and Dissent (2015), 3, at 9.

${ }^{50}$ S. B. Twiss and J. Chan, 'The Classical Confucian Position on the Legitimate Use of Military Force', (2012) 40 Journal of Religious Ethics 447, at 452.

${ }^{51}$ Bloom, supra note 36 , at 44 , para. $2 \mathrm{~B} 8$.

${ }^{52}$ Watson, supra note 35 , at 115 , para. 2 .
} 
morality. When he behaved tyrannically against the principle of benevolence and justice, he would lose his Mandate of Heaven to rule. ${ }^{53}$ In this case, other entities, such as the feudal lords and rebels, could obtain the authority to set about waging just war. Mencius, while insisting that there was no just war recorded in The Spring and Autumn Annals due to the Chinese monarch's absence, ${ }^{54}$ conceded that the monarch's moral superiority and concomitant war-making authority could possibly fall into the hands of the righteous feudal lords if he offended against humaneness and rightness. ${ }^{55}$ In a similar vein, the competence of the leaders of mass rebellions might be approved on the condition that they genuinely fought to overthrow tyrants who wrecked the social order and pained the populace. ${ }^{56}$

Secondly, a just war must have a justifiable cause. Taking just war basically as punishment of moral inferiors, ancient Chinese thinkers installed this concept within the domain of the enforcement of criminal justice. As said by Wenzhong Zang, a politician during the Spring and Autumn period, 'the first-grade criminal punishment is war; the second-grade is sword and saw; the thirdgrade is whip and bamboo'. ${ }^{57}$ Guanzi also submitted that 'when punishing an aggressor state, it is necessary to use armed forces. When restraining perverse people, it is necessary to apply punishments. Thus the armed forces are used externally to punish aggression and internally to restrain wickedness' ${ }^{58}$ Accordingly, the conceptual boundary between just war and domestic criminal law enforcement was too obscure to be discerned. Just war was seen as homologous with coercive punitive measures taken against criminals, differing only in scale. ${ }^{59}$ For this reason, the aim of just war was formulated as 'consoling the people and punishing the wicked (吊民伐罪)'60 or 'prohibiting violent and aggressive behaviour and preventing harm to others (禁暴除害)'61 - not dissimilar from the one of criminal justice.

A multiplicity of Chinese classics sets forth justifiable causes for launching a punitive expedition. ${ }^{62}$ Among them, Rites of Zhou (周礼) provides the most detailed list of heinous offences, on both political and humanitarian grounds, that would incur punitive expeditions, including an incumbent ruler of a state bullying weaker states, persecuting his people, being internally tyrannical and externally insulting, neglecting agriculture, being recalcitrant to the Chinese monarch, killing his relatives, exiling or murder his former king, defying the order of the Chinese monarch, and transgressing human ethics like a wild animal. ${ }^{63}$ All these offences were taken as flagrant outrages against the moralized political order. To penalize the perpetrators of these offences and restore the peace and order of Tianxia then justified resorting to war. For Confucian scholars, such construction of causes for just war would be an explanation for the morphological phenomenon that in Chinese the character '征 (punitive expeditions)' is cognate with the character '正 (to

\footnotetext{
${ }^{53}$ Y. Tong, 'Morality, Benevolence, and Responsibility: Regime Legitimacy in China from Past to the Present', (2011) 16 Journal of Chinese Political Science 141, at 146.

${ }^{54}$ Bloom, supra note 36 , at 156 , para. $7 \mathrm{~B} 2$.

${ }^{55} \mathrm{Ibid}$., at 22, para. 1B8. In such a case, a tyrant was treated as a 'brigand' and an 'outlaw', and should be removed. See ibid.

${ }^{56} \mathrm{X}$. Yao, 'Conflict, Peace and Ethical Solutions: A Confucian Perspective on War', (2004) 4 Sungkyun Journal of East Asian Studies 89, at 96 .

57国语 [Discourses of the States] (2015), Zhao Wei (anno.), 107.

${ }^{58}$ Rickett, supra note 45, 393.

${ }^{59}$ R. McNeal, Conquer and Govern: Early Chinese Military Texts from the Yi Zhou Shu (2012), 41. Stephen Neff made a similar observation: 'China did not have - and indeed could not have had - a fully fledged conception of war ... The crucial conceptual divide in Chinese thought was not between domestic law enforcement and foreign war, but rather between different forms of law enforcement.' See Neff, supra note 17, at 20.

60 三字经·百家姓.千字文·弟子规 [Three Character Classic, Hundred Family Surnames, Thousand Character Classic and Disciple Gauge] (2009), 138. See also Bloom, supra note 36, at 66, para. 3B5.

${ }^{61}$ Knoblock, supra note 37, at 228, para. 15.2. See also 'Wei Liao-tzu', in Sawyer, supra note 43, at 254; 'Three Strategies of Huang Shih-kung', in ibid., at 305.

${ }^{62}$ For a tabular presentation of those causes see C. Chang, 'Were Those Decisions Righteously Made? The Chinese Tradition of Righteous War and Chinas Decisions for War, 1950-1979', (2017) 13 Foreign Policy Analysis 398, at 400.

63 周礼 [Rites of Zhou] (2010), 254.
} 
correct) ${ }^{64}$ In any case, in the Chinese tradition, punitive expeditions approximated but did not equal the slightly broader concept of just war, because defence of one's own state against unjustifiable invasion also counted as a just cause. ${ }^{65}$

\section{Harmonizing the means with the end: Chinese perspectives on the ad bellum/in bello relationship}

Discussions on last resort, authority, and causes for just war all fall into, in modern-day parlance, the purview of jus ad bellum. On the other side of the coin, what is now known as jus in bello also has an essential stake in the Chinese just war tradition, making up another criterion for just war. It is the formulation of the role of jus in bello that marks the distinctiveness of Chinese perspectives on the ad bellum/in bello relationship.

\subsection{Jus in bello as a constituent element of just war in the Chinese tradition}

In the Chinese tradition, the indispensability of jus in bello immediately rests in the tail end of the jus ad bellum logic chain which conceptualizes just war as enforcement of criminal punishment under the principle of benevolence and justice. Since just war in general meant punishing with arms those who were responsible for atrocities, brutalities, and chaos, a basic distinction was drawn between the guilty and the innocent with a view to inflicting punishment. Only the former were labelled as adversaries. For instance, King Cheng of Zhou announced to the adherents of the Shang dynasty that in the punitive war undertaken by Zhou against Shang, Zhou only regarded the royal house of Shang as the enemy. ${ }^{66}$ For ancient Chinese thinkers, it followed neatly that the military violence during just war should be directed only at those who were guilty; the innocent yearning for peace and order were not punishable, and war's adverse effects on them should be, in theory, averted. ${ }^{67}$ Therefore, as a basic principle, when fighting a just war, a belligerent ought not to harass or harm innocent people. ${ }^{68}$

Upon this elementary guilt-innocence dichotomy, a number of Chinese classics itemize detailed 'dos and don'ts' for the troops which claimed themselves to be just. For example, Huainanzi establishes prohibitions on enslaving people, disturbing graves, scorching grains, burning property, and stealing domestic animals. ${ }^{69}$ T'ai Kung's Six Secret Teachings offers the following rules:

Do not set fire to what the people have accumulated; do not destroy their palaces or houses, nor cut down the trees at gravesites or altars. Do not kill those who surrender nor slay your captives. Instead show them benevolence and righteousness, extend your generous [v]irtue to them. ${ }^{70}$

A more elaborate proposal is found in The Methods of the Ssu-ma:

\footnotetext{
${ }^{64}$ See Bloom, supra note 36, at 157, para. 7B4; X. Zhu, 四书章句集注 [Collected Annotations of the Four Books] (1983), 364.

${ }^{65}$ See Bloom, ibid., at 24, para. 1B13; Ryden, supra note 42, at 143; 'Wei Liao-tzu', in Sawyer, supra note 43, at 274; The Mozi (墨子): A Complete Translation (2010) (translated by I. Johnston), 195, para. 19.9.

${ }^{66}$ The Chinese Classics, Vol. III: The Shoo King or The Book of Historical Documents (尚书) (1865) (translated by J. Legge), 458.

${ }^{67}$ Y. Yu, 'Military Ethics of Xunzi: Confucianism Confronts War', (2006) 35 Comparative Strategy 260, at 269.

${ }^{68} \mathrm{Knoblock}$ and Riegel, supra note 43, at 186, para. 7/5.3; The Huainanzi (淮南子): A Guide to the Theory and Practice of Government in Early Han China (2010) (translated by J. S. Major et al.), 583. In an idealistic manner, Mencius and Xunzi both argued that a humane and righteous king should not even perform one unjust act or execute one blameless man. See Bloom, supra note 36, at 32, para. 2A2; Knoblock, supra note 37, at 150, para. 11.1a.

${ }^{69}$ Major et al., supra note 68 , at 582.

${ }^{70}$ 'T'ai Kung's Six Secret Teachings', in Sawyer, supra note 43, at 87.
} 
In antiquity [the armies of the sage kings] did not pursue a fleeing enemy more than one hundred paces or follow a retreating enemy more than three days, thereby making clear their observance of the forms of proper conduct [礼]. They did not exhaust the incapable and had sympathy for the wounded and sick, thereby making evident their benevolence. They awaited the completion of the enemy's formation and then drummed the attack, thereby making clear their good faith ... Moreover, they were able to pardon those who submitted ... ${ }^{71}$

When you enter the offender's territory, do not do violence to his gods; do not hunt his wild animals; do not destroy earthworks; do not set fire to buildings; do not cut down forests; do not take the six domesticated animals, grains, or implements. When you see their elderly or very young, return them without harming them. Even if you encounter adults, unless they engage you in combat, do not treat them as enemies. If an enemy has been wounded, provide medical attention and return him. ${ }^{72}$

The contents of these jus in bello norms closely parallel some elements of IHL, although in much more germinal forms and in a non-legal sense. Persons who fell under protection covered civilians in general, elders and children in particular, the captives, the wounded and sick, and those who surrendered. They should not be executed, injured or enslaved. Protected objects were those which were not, or no longer, utilized by the administration of the foe, normally including private property (houses, crops, grains and livestock), graves, supplies, trees, and wild animals. They should not be confiscated or destroyed. Furthermore, there were rules on the conduct of hostilities, including the requirement to observe proprieties on the battlefield and the prohibition of pillage. Regulated under these norms, the army of the just belligerent was specially denominated as an 'Army of Benevolence and Justice (仁义之师)', a civilized force trained with propriety and benevolence, expected to adhere to kindheartedness and humanity in the course of warfare, and supposed to be welcomed by the populace in the war-affected zones. As Xunzi envisaged, ' $[w]$ herever the army of a humane man is, it has an effect like that of a spirit; wherever it travels, it produces transformation. Like seasonable rains, it pleases and gives joy to all'. ${ }^{73}$

In the Chinese tradition, the dimension of jus in bello was not simply an accessory of jus ad bellum. In contrast, it was one of the constituent elements of just war, carrying the equivalent weight as the cause in the determination of the nature of war. Just exactly as a just war could not lack a justifiable cause, infringement of the norms governing conduct during war would comparably render a war unjust - even though its cause was flawless at the outset. Such a mode of thinking can be easily traced in Chinese philosophical and historical books.

Mencius, in a conversation with King Xuan of Qi, by first making exemplary just wars conducted by the sage Tang, enlightened the King that:

Now, Yan oppressed its people, and you went and punished its ruler. The people believed you were going to deliver them from out of the flood and fire and, bringing baskets of rice and pitchers of drink, they welcomed your army. Then you slew their fathers and older brothers, bound their sons and younger brothers, destroyed their ancestral temple, and carried off their treasured vessels - how can this be condoned? ${ }^{74}$

\footnotetext{
${ }^{71}$ 'The Methods of the Ssu-ma', in ibid., at 126-7 (internal citations omitted).

${ }^{72}$ Ibid., at 128 (internal citations omitted).

${ }^{73}$ Knoblock, supra note 37 , at 228 , para. 15.2 .

${ }^{74}$ Bloom, supra note 36 , at $23-4$, para. $1 \mathrm{~B} 11$.
} 
Without forthright rebuke, Mencius modestly suggested to the King that his war was morally flawed due to the atrocities committed by his men. On another occasion, Mencius expressed his doubt over the nature of an alleged just war recorded in a book when he noticed that that war resulted in a horrendous death toll. 'When the one who was most humane attacked the one most devoid of humaneness', he interrogated, 'how could it have been possible that "the blood flowed so that it floated the pestles of the mortars"? 75

During the Spring and Autumn period, the state of Wu once made an incursion into the state of Chen, for the professed purpose of punishing offences committed by the latter. In the prosecution of the war, Wu's army destroyed the places of sacrifice and put to death those who were suffering from a pestilence. The Grand-administrator of Chen, when speaking with the king of $\mathrm{Wu}$ at the close of the campaign, frankly called into question the justness of Wu's war by referring to those outrages. ${ }^{76}$

In 36, the final year in his war to reunify China, Emperor Guangwu of the Han dynasty ordered his two generals to attack his last enemy in Chengdu. While the enemy was vanquished, his generals committed slaughter, robbery, and arson when taking over the city. The furious Emperor issued a reprimand:

The city has surrendered for three days. Both the government officials and civilians submitted. Just counting children and old mothers there were at least ten thousands of them. When you got the soldiers to set arson on them, everyone who would hear this news would be deeply saddened ... How can you bear to do such a wrong! ... You have lost the righteousness/justice of executing the enemy's general and comforting the people! ${ }^{77}$

The Emperor Taizu of the Ming dynasty, in his military campaign against the ruling Mongols of the Yuan dynasty in 1368, said to his generals that:

The earlier revolutionaries did much reckless slaughtering [of the Mongolian people]. Such conduct is contrary to Heaven as well as abusive to people, I cannot bear to see it. You, my generals, should refrain from reckless arson, robbery, and killing when you conquer a city. Even for the Yuan royalty's clan relatives you should spare them. I do this to thank Heaven and to comfort people, and hopefully my campaign can conform to my intention of punishing the guilty and comforting the people. Those of you who disobey this order will be punished with no amnesty. ${ }^{78}$

These episodes, running through the historical periods of Spring and Autumn, Warring States and Imperial China, consistently point to a set of time-honoured ideas on the relationship between jus ad bellum and jus in bello: First, a just war should intrinsically be conducted in a just way; second, respecting and implementing jus in bello would manifest the justness of the cause that provides a prima facie justification for a war under jus ad bellum; and third, failing to observe jus in bello would retroactively put the alleged justness (of the cause) of a war at stake. ${ }^{79}$ The Chinese just war tradition was of a distinctly holistic understanding of the ad bellum/in bello relationship: The

\footnotetext{
${ }^{75}$ Ibid., at $156-7$, para. $7 \mathrm{~B} 3$.

${ }^{76}$ Couvreur, supra note 32, at 218-20.

${ }^{77}$ G. Sima, 资治通鉴 [Comprehensive Mirror to Aid in Government] (2017), vol. I, Guoyi Wu (anno.), 441, translation cited from P. Lo, 'The Art of War Corpus and Chinese Just War Ethics Past and Present', (2012) 40 Journal of Religious Ethics 404, at 429-30 (emphasis added).

${ }^{78}$ Tingyu Zhang, 明史 [History of the Ming Dynasty] (1996), vol. I, at 11, translation cited from Lo, ibid., at 431 (emphasis added).

${ }^{79} \mathrm{~A}$ similar conclusion was reached by Ping-cheung Lo, who claimed that in the Chinese just war ethics, '[a] righteous war certainly should be conducted in a righteous manner', and 'the just cause that justifies the war needs to be manifested in the conduct during war'. See Lo, ibid., at $418,419$.
} 
means (jus in bello) and the end (jus ad bellum) were harmonized with one another; they formed an integral whole and were ethically inseparable. ${ }^{80}$

\subsection{The continuing validity of the holistic understanding in modern Chinese military ethics}

Along with the country's gradual modernization and integration into the egalitarian Westphalian international order since the nineteenth century, China's conception of war has been remoulded to a great extent, in particular with regard to the corpus of jus ad bellum. Military Terminology of the Chinese People's Liberation Army (中国人民解放军军语), the official military dictionary of the Chinese People's Liberation Army, defines the term 'just war', from a jus ad bellum angle, as:

wars that serve the fundamental interests of the people and promote social progress, including those conducted for the purposes of opposing the oppression of reactionary classes, striving for national liberation, resisting external invasion, safeguarding national unity, and maintaining world peace. ${ }^{81}$

These causes certainly bear little resemblance to those enumerated in Chinese classics like Rites of Zhou.

Be that as it may, concerning the ad bellum/in bello relationship in an ethical, if not legal, level, China continues to retain the age-old holistic mind-set judging the justness (of the cause) of war largely from that of the conduct during war. During the negotiation of the additional protocols to the 1949 Geneva Conventions, China, insisting on a distinction between just and unjust wars to be made in the forthcoming protocols, ${ }^{82}$ conspicuously argued that:

[T] he type of weapons used was closely related to the type of war. The aggressor, who conducted an unjust war, was likely to use cruel and genocidal weapons, whereas just wars were precisely directed against the use of such weapons. ${ }^{83}$

\footnotetext{
${ }^{80}$ Regrettably, however, the effectiveness of the exquisite Chinese just war theory in preventing the occurrence of war and curbing the brutality of warfare should not be exaggerated, for China's history is no more peaceful (nor violent) than other civilizations. Thousands of wars have been fought by all kinds of Chinese belligerents, in which there has been no shortage of flagitious actions committed. An often-mentioned example is the state of Qin's enormity of slaughtering 400,000 surrendered or captured Zhao soldiers straight after the Battle of Changping in 260 BC. In effect, historians who investigated several selected court debates in China before 1949 found that, at least on such occasions, the moral acceptability of wars was more often than not set aside by Chinese statesmen and generals. Most debates were concerned with pragmatic cost-benefit questions, and with how to go about using force in the most effective way possible. See P. A. Lorge, 'Introduction', in P. A. Lorge (ed.), Debating War in Chinese History (2013), 1, at 1, 10.

${ }^{81}$ 中国人民解放军军语 [Military Terminology of the Chinese People's Liberation Army] (2011), 47. The jus ad bellum aspect of contemporary Chinese just war ethics is dominated by Marxism-Leninism which has been established as the state ideology of China since the government of the People's Republic of China came into power in 1949. Marxism-Leninism defines just war as revolutionary or progressive war, and unjust war as anti-revolutionary or reactionary war. In capitalist states, wars against the people's oppressors and enslavers - the bourgeoisie - are just pursuant to their cause. Fighting for national liberation, 'expressive of the mass movement against national oppression', is also considered a just cause. In contrast, 'imperialist wars', that is, 'wars for world domination, for markets for banking capital and for the subjugation of small and weaker nations', are unjust wars par excellence. For this strand of thought see V. I. Lenin, 'Revolutionary Army and Revolutionary Government', in V. I. Lenin Collected Works (1962), vol. VIII, at 565; V. I. Lenin, 'A Caricature of Marxism and Imperialist Economism', in V. I. Lenin Collected Works (1964), vol. XXIII, at 33; V. I. Lenin, 'Materials Relating to the Revision of the Party Programme', in V. I. Lenin Collected Works (1964), vol. XXIV, at 459; Z. Mao, 'On Tactics against Japanese Imperialism', in Selected Works of Mao Tse-Tung (1965), vol. I, at 170.

${ }^{82}$ Official Records of the Diplomatic Conference on the Reaffirmation and Development of International Humanitarian Law Applicable in Armed Conflicts (Geneva, 1974-1977), vol. V, at 120, para. 15.

${ }^{83}$ Official Records of the Diplomatic Conference on the Reaffirmation and Development of International Humanitarian Law Applicable in Armed Conflicts (Geneva, 1974-1977), vol. XVI, at 458, para. 24 (emphasis added).
} 
Accordingly, to unveil the unjustness of wars waged by 'imperialists, colonialists and aggressors', China condemned the use of 'cruel and genocidal weapons' and 'barbarous methods of combat' by these belligerents. ${ }^{84}$ The traditional linkage of the justness of the means of warfare to that of the cause for war was sustained. On this occasion, China's presentation of the ad bellum/in bello relationship in such a pattern was distinctive among states in favour of the introduction of the just war language into the system of IHL. ${ }^{85}$

Likewise, during the negotiation of the Convention on Certain Conventional Weapons, China expressed its wish for this future jus in bello convention to 'be linked to the struggle of the world's peoples against aggression' - a matter of jus ad bellum. ${ }^{86}$ In 1981, China stated that the basic spirit of this convention, which is to prohibit or restrict the use of excessively injurious and indiscriminative weapons, conforms to its 'consistent position' and serves 'the interest of opposing aggression and maintaining peace'. ${ }^{87}$ The country made a similar statement vis-á-vis the Biological Weapons Convention in $1984 .{ }^{88}$ These particular statements mirror China's military ethics treating the ban on the use of inhumane weapons as an intrinsic requirement of just war, such as wars 'opposing aggression and maintaining peace'.

The holistic understanding of the ad bellum/in bello relationship is also reiterated in voluminous Chinese military publications. ${ }^{89} \mathrm{~A}$ commentary published by the Chinese People's Liberation Army further makes clear that even for a war commencing with a just cause, grave violations of jus in bello nullify the just title that it tentatively garners:

[T] he justness of war depends on not only whether the end of war is just, but also whether the means of war is just; we should not only adhere to jus ad bellum but also pay attention to jus in bello. The anti-human and anti-social conduct during warfare, such as the use of weapons of mass destruction, will lose the support of the general populace and, as a consequence, alter the nature of the war. ${ }^{90}$

\footnotetext{
${ }^{84}$ Ibid., at 26, para. 6; Official Records of the Diplomatic Conference on the Reaffirmation and Development of International Humanitarian Law Applicable in Armed Conflicts (Geneva, 1974-1977), vol. V, at 120 , para. 18. Correspondingly, to manifest the justness of wars of national liberation, China claimed that such wars 'were directed against' the use of 'cruel and genocidal weapons'. See Official Records of the Diplomatic Conference on the Reaffirmation and Development of International Humanitarian Law Applicable in Armed Conflicts (Geneva, 19741977), vol. XVI, at 26, para. 6; at 458, para. 24.

${ }^{85}$ During this conference, only a few delegations candidly expressed their intention to introduce the dichotomy between just and unjust wars into IHL. Apart from China, Albania was another active promoter of the explicit use of the just war language in Additional Protocol I at issue. It did not, however, build its argumentation for the justness of wars of national liberation upon jus in bello. For Albania's statements in relation to just war see Official Records of the Diplomatic Conference on the Reaffirmation and Development of International Humanitarian Law Applicable in Armed Conflicts (Geneva, 1974-1977), vol. V, at 146, para. 25; Official Records of the Diplomatic Conference on the Reaffirmation and Development of International Humanitarian Law Applicable in Armed Conflicts (Geneva, 1974-1977), vol. VIII, at 88, para. 10; Official Records of the Diplomatic Conference on the Reaffirmation and Development of International Humanitarian Law Applicable in Armed Conflicts (Geneva, 1974-1977), vol. XIV, at 70, paras. 85-6; Official Records of the Diplomatic Conference on the Reaffirmation and Development of International Humanitarian Law Applicable in Armed Conflicts (Geneva, 1974-1977), vol. XVI, at 28, para. 15.

${ }^{86}$ UN Doc. A/CONF.95/SR.4 (1979), at 4, para. 18.

${ }^{87}$ UN Department for Disarmament Affairs, Status of Multilateral Arms Regulation and Disarmament Agreements (1997), at 214.

${ }^{88}$ Ibid., at $172-3$.

${ }^{89}$ See, e.g., S. Leng and H. Wang, 法律战教育训练读本 [Legal Warfare Education and Training Reader] (2004), 8; W. Cong, X. Wang and Q. Zhong, 法律战100例 $\square$ 经典案例评析 [One Hundred Cases for Legal Warfare: Analyses of Classical Cases] (2004), 134-5.

${ }^{90}$ G. Kang, 关于当代战争观的几个问题 [Several Questions about the Contemporary Conception of War], People's Liberation Army Daily, 19 September 2014, 11.
} 
In addition, the Chinese People's Liberation Army, by labelling itself as an 'Army of Benevolence and Justice' - a term picked up from the Chinese just war tradition, ${ }^{91}$ purports to build a public image that it would act as a civilized force in pursuit of just causes, just as the army of the mythical Chinese sage kings (who, according to the conventional wisdom, categorically fought for justice) did thousands of years ago.

It can be concluded from these examples that the holistic understanding of the ad bellum/in bello relationship which originated from the Chinese just war theory still holds sway in contemporary Chinese military ethics. ${ }^{92}$ Such a mind-set has been well internalized as one of the factors guiding China's IHL practice. It is noteworthy that although with distinctive ethical perspectives, China, by embracing the IHL system, does not reject the ad bellum/in bello separation as a matter of positive law. Nevertheless, Chinese perspectives on the ad bellum/in bello relationship would have implications on how the ad bellum/in bello relationship could be better evaluated, in both legal and ethical domains.

\section{A cultural critique of the ad bellum/in bello separation in IHL in light of Chinese perspectives}

The Chinese conception of war, with a holistic understanding of the ad bellum/in bello relationship, did not, and could not, in and of itself give birth to a norm of the ad bellum/in bello separation. As presumed earlier in this article, the ad bellum/in bello separation is of a Western cultural imprint. This presumption may be examined by looking into the origin of this separatist norm and the proffered rationale for it, in light of Chinese perspectives that have been described.

\subsection{From Rome to Geneva: The western origin of the ad bellum/in bello separation}

In the West, the ad bellum/in bello relationship was also first touched upon as an ethical issue within the realm of the just war theory which formed the crux of the conception of war. Compared with its Chinese counterpart, the European and Western conception of war varied to a much greater extent at successive historical stages.

The European doctrinal distinction between just and unjust wars can be traced back to ancient Rome. ${ }^{93}$ Pursuant to the Roman just war theory, a valid cause such as defence of Roman dominions was necessary for a war to be considered just. ${ }^{94}$ Furthermore, a couple of procedural rules, including a declaration of war, ought to be executed before a just war was fought. ${ }^{95}$ Beyond these jus ad bellum limits, however, little thought was given to the jus in bello requirements. Out of the belief that the declaration of war abrogated any obligation to respect the enemy's rights, the Roman just war countenanced excesses. ${ }^{96}$ In Roman eyes, 'the conduct of war was essentially

\footnotetext{
${ }^{91}$ See, e.g., 仁义之师, 得人心者必胜 [An Army of Benevolence and Justice: Those Who Win People's Heart Are Bound to Win], Jiefang Daily, 1 August 2007, 7; J. Hu et al., 瓦砾间,仁义之师真本色 [Among the Rocks and Debris, the True Colours of an Army of Benevolence and Justice], People's Liberation Army Daily, 12 August 2014, 1.

${ }^{92}$ In effect, it becomes imperative nowadays for the Chinese government and armed forces, which are often reluctant to endorse Western notions, to retrieve knowledge from rich Chinese traditions, for the sake of the advancement of their ethics of war. See P. Lo, 'Chinese Traditions on Military Ethics', in J. T. Johnson and E. D. Patterson (eds.), The Ashgate Research Companion to Military Ethics (2015), 399, at 411. As Ping-cheung Lo noted, the Chinese government wants to articulate its own unique voice rather than adopting the voices of others. It could be a matter of national dignity for the Chinese government that China stands on equal footing with the West, which prevents it from simply following suit. See Ping-cheung Lo, 'Warfare Ethics in Sunzi's Art of War? Historical Controversies and Contemporary Perspectives', (2012) 11 Journal of Military Ethics 114, at 125.

${ }^{93}$ Y. Dinstein, War, Aggression and Self-Defence (2011), 65.

${ }^{94}$ The ancient Roman understood the just causes for war as retaliation for four offences: Violation of the Roman dominions; violation of ambassadors; violation of treaties; and support to an enemy of Rome by a hitherto friendly state. See G. I. A. D. Draper, 'The Origins of the Just War Tradition', (1964) 46 New Blackfriars 82, at 82.

${ }^{95}$ Cicero, De Officiis (1913) (translated by W. Miller), 39.

${ }^{96}$ F. H. Russell, The Just War in the Middle Ages (1975), 7.
} 
unrestrained. Prisoners could be enslaved or massacred; plunder was general; and no distinction was recognized between combatants and non-combatants'. ${ }^{97}$

The advent of the theological just war theory followed the Christianization of the Roman Empire. Augustine of Hippo was the first major theologian who built Christian pacifism into the edifice of just war. He preached that while it is the wrong-doing of the opposing party which compels the wise man to wage just wars', ${ }^{98}$ 'war is waged in order that peace may be obtained' .99 However, he said little directly on the topic of restricting the prosecution of war once begun. ${ }^{100}$ Centuries later, this theological theory was elaborated on by Thomas Aquinas, who put forward three criteria for just war: first, a just war had to be waged under the authority of the sovereign instead of a private individual; second, a just war must have a just cause, namely, avenging wrongs; and third, the belligerents must be animated by a rightful intention of advancing good or avoiding evil. ${ }^{101}$ As for the issue of jus in bello, while giving a few occasional comments, ${ }^{102}$ Aquinas, like other theologians, did not articulate a cluster of distinct and coherent precepts. ${ }^{103}$

It was not until the close of the Middle Ages that scholars, known as 'fathers' of international law, embarked on filling the gaps in the European just war tradition by supplementing it with a meaningful jus in bello dimension. Francisco de Vitoria took a lead in this venture. He claimed that a war may be just on both sides when 'there is right on one side and ignorance on the other', ${ }^{104}$ because the latter party, acting with 'provable ignorance', was exonerated for its conviction that its cause was just. ${ }^{105}$ Vitoria then applied this doctrine to his analysis of the contemporary Spanish conquest of the Americas: As Indians were not guilty for not knowing the Spanish's 'just titles' to conquer them, damage and loss inflicted on them should be as little as possible. ${ }^{106}$ Vitoria also forcefully argued that, as the foundation of a just war is the injury caused by the wicked, not by innocents who did no harm, it was, in principle, impermissible to kill innocent members of the enemy population, such as children, women, travellers, and monks, for the injury done by the wicked among them. ${ }^{107}$

Hugo Grotius, referring to the issue of jus in bello in parallel with that of jus ad bellum, added new weight to it in the European just war discourse:

I saw prevailing throughout the Christian world a license in making war of which even barbarous nations would have been ashamed; recourse being had to arms for slight reasons or no reason; and when arms were once taken up, all reverence for divine and human law was thrown away, just as if men were thenceforth authorized to commit all crimes without restraint. ${ }^{108}$

\footnotetext{
${ }^{97}$ R. C. Stacey, 'The Age of Chivalry', in M. Howard, G. Andreopoulos and M. R. Shulman (eds.), The Laws of War: Constraints on Warfare in the Western World (1994), 27, at 27.

${ }^{98}$ Augustine, The City of God (1871), vol. II (translated by M. Dods), 311.

${ }^{99}$ 'No. 42 (Ep. CLXXXIX)', in St. Augustine Select Letters (1930) (translated by J. H. Baxter), 323, at 331.

${ }^{100}$ J. T. Johnson, Just War Tradition and the Restraint of War: A Moral and Historical Inquiry (1981), 123.

${ }^{101}$ The 'Summa Theological' of St. Thomas Aquinas (1917) (translated by the Fathers of the English Dominican Province), vol. IX, at 501-2.

${ }^{102}$ See A. J. Bellamy, Just Wars: From Cicero to Iraq (2006), 40; J. Finnis, 'The Ethics of War and Peace in the Catholic Natural Law Tradition', in J. A. Coleman (ed.), Christian Political Ethics (2008), 191, at 202-3.

${ }^{103}$ See Stacey, supra note 97 , at 30 . The general lack of scruples about jus in bello led to the paucity of concrete rules for restraining the conduct of warfare in Medieval Europe. One ecclesiastical rule that is commonly noted is a ban adopted in the Second Lateran Council of 1139 on the use of crossbows, bows and arrows, and siege machines against Christians. See Russell, supra note 96, at 156; Johnson, supra note 100, at 123. There were also a handful of secular rules deviating from the chivalric code. For example, in the ordinary circumstances of battle, a knight ought not to kill another knight if it was possible instead to capture him for ransom (conversely, armed peasants and townsmen could be massacred at will.) See Stacey, supra note 97, at 30.

${ }^{104}$ F. de Vitoria, 'On the American Indians', in A. Pagden and J. Lawrance (eds.), Francisco de Vitoria Political Writings (1991), 231, at 282.

${ }^{105} \mathrm{~F}$. de Vitoria, 'On the Law of War', in ibid., 293, at 313.

${ }^{106}$ F. de Vitoria, 'Letter 1: Letter to Miguel de Arcos, OP Salamanca, 8 November [1534]', in ibid., 331, at 332.

${ }^{107} \mathrm{~F}$. de Vitoria, 'On the Law of War', in ibid., 293, at 314-15.

${ }^{108}$ Grotius on the Rights of War and Peace: An Abridged Translation (1853) (translated by W. Whewell), xxxi (emphasis added).
} 
Approving of the possibility for a war to be subjectively just for both parties, ${ }^{109}$ Grotius contended that 'moderation' in just war was required by the law of nature, in order that the extravagant licence of war could be retrenched into 'what natural [e]quity allows' or 'what is best among [t]hings lawful'. ${ }^{110}$ As he argued, non-combatants such as children, women, priests, scholars, and merchants were all potential innocents; a just belligerent must not attempt anything which may prove the destruction of innocents, unless for some extraordinary reasons, and for the safety of many. ${ }^{111}$

Standing on the shoulders of his predecessors, Emmerich de Vattel utilized the principle of equality among sovereigns to substantiate the idea that a war could be just on both sides. ${ }^{112}$ Reducing casualties during war therefore became morally compelling. A general rule of the law of nature, as Vattel submitted, was that '[a]ll damage done to the enemy unnecessarily, every act of hostility which does not tend to procure victory and bring the war to a conclusion, is a licentiousness condemned by the law of nature. ${ }^{113}$ Specifically, he mentioned women, children, feeble old men, and sick persons, denying any right to 'maltreat their persons', 'use any violence against them' or 'take away their lives'. ${ }^{114}$ More importantly, Vattel was the first to enunciate the idea that the law of nations (in contrast with the law of nature) equally authorized both belligerents regardless of their causes - the original prototype of the ad bellum/in bello separation: 'The justice of the cause being reputed equal between two enemies, whatever is permitted to the one in virtue of the state of war, is also permitted to the other.' ${ }^{\text {'15 }}$

The rise and prevalence of legal positivism in the nineteenth and the early twentieth centuries, with the expelling of 'non-law' from legal discourse, put an end to the marriage between just war and international law. Legal positivism ruthlessly relegated the natural law concept of just war as pure morality - essentially an ethical rather than legal matter. ${ }^{116}$ In the words of George Davis, ' $[w]$ ith the inherent rightfulness of war international law has nothing to do'. ${ }^{117}$ At the same time, war per se was characterized as an instrument of national policy, to be deployed for any reason at a sovereign's discretion. ${ }^{118}$ Accordingly, jus ad bellum was also pushed beyond the sphere of international law. As a result, international law failed to yield any legal instrument distinguishing between the legal and illegal use of force. ${ }^{119}$ The

\footnotetext{
${ }^{109}$ H. Grotius, The Rights of War and Peace (2005), Book II, R. Tuck (ed.), 1130.

${ }^{110} \mathrm{H}$. Grotius, ibid., Book III, 1472. Grotius has been widely credited for his invention of the concept of 'moderation in war' (temperamenta belli, in his terminology). See, e.g., Johnson, supra note 100, at 178-9; G. Best, 'The Place of Grotius in the Development of International Humanitarian Law', in A. Dufour, P. Haggenmacher and J. Toman (eds.), Grotius et l'Ordre Juridique International: Travaux du Colloque Hugo Grotius, Genève, 10-11 Novembre 1983 (1985), 101, at 105; G. I. A. D. Draper, 'The Development of International Humanitarian Law', in International Dimensions of Humanitarian Law (1988), 67, at 67; K. Nabulsi, 'Conceptions of Justice in War: From Grotius to Modern Times', in R. Sorabji and D. Rodin (eds.), The Ethics of War: Shared Problems in Different Traditions (2006), 44, at 46. However, in the ambit of the law of nations where the natural law idea of moderation held no place, Grotius did not recognize any restraint of warfare. See G. I. A. D. Draper, 'Grotius' Place in the Development of Legal Ideas about War', in H. Bull, B. Kingsbury and A. Roberts (eds.), Hugo Grotius and International Relations (1990), 177, at 198.

${ }^{111}$ Grotius, supra note 110 , at 1439-46.

${ }^{112}$ E. de Vattel, The Law of Nations, or, Principles of the Law of Nature, Applied to the Conduct and Affairs of Nations and Sovereigns, with Three Early Essays on the Origin and Nature of Natural Law and on Luxury (2008), B. Kapossy and R. Whatmore (eds.), 489.

${ }^{113}$ Ibid., 573.

${ }^{114}$ Ibid., 589.

${ }^{115}$ Ibid., 591 (emphasis omitted).

${ }^{116}$ T. J. Lawrence, The Principles of International Law (1928), P. H. Winfield (ed.), 311. In effect, in the eyes of legal positivists, even the entire system of natural law is no more than a sort of a thing called "a moral system, formed by ethical writers"'. See J. Bentham, A Comment on the Commentaries and a Fragment on Government (2008), J. H. Burns and H. L. A. Hart (eds.), 298.

${ }^{117}$ G. B. Davis, The Elements of International Law: With an Account of Its Origin, Sources, and Historical Development (1916), G. E. Sherman (ed.), 272.

${ }^{118}$ R. D. Sloane, 'The Cost of Conflation: Preserving the Dualism of Jus ad Bellum and Jus in Bello in the Contemporary Law of War', (2009) 34 Yale J. Int'l L. 47, at 62.

${ }^{119}$ J. L. Brierly, 'International Law and Resort to Armed Force', (1932) 4 Cambridge L. J. 308, at 308.
} 
codification of the international law of war at that time, as reflected in major treaties such as the 1864 Geneva Convention and the 1899 and 1907 Hague Conventions, was only capable of zooming in on the conduct of warfare, making no reference to either the justness of war (an ethical issue) or the legality of resorting to war (a matter yet to be regulated by international law). ${ }^{120}$ Upon this positivist viewpoint, it became a natural course to emancipate, in the field of law, jus in bello from the long-standing reign of jus ad bellum.

It was at the time of the League of Nations, during which the Western-dominated international law set out to saddle the use of force with substantial constraints, that jus ad bellum returned to the sight of international law and the two bodies of law first came to be examined on an equal footing, ${ }^{121}$ although no longer in a just war or ethical context. Since Josef Kunz, an Austrian international lawyer, stamped them with Latin names in 1930s, the use of the twin terms ' $j u s$ ad bellum' and 'jus in bello' has started to gain currency in academia. ${ }^{122}$

The formal establishment of the theoretical ad bellum/in bello distinction in the first half of the twentieth century was not the end of this journey. In concert with the new trend which gave parallel analyses on the two, international rules were adopted to formally guarantee their autonomy from each other. Therefore, core IHL instruments developed from then on commonly underline the equal application of their rules to both sides of the conflict regardless of the reasons for going to war. Common Article 1 of the 1949 Geneva Conventions affirms the applicability of these conventions 'in all circumstances'. ${ }^{123}$ This Article, as interpreted by the ICRC, 'reaffirms the strict separation of jus ad bellum and jus in bello ... In other words, the application of the Conventions does not depend on the legal justification for the conflict under the jus ad bellum'. ${ }^{124}$ Additional Protocol I to the Geneva Conventions contains a more unambiguous reference to the equal application of IHL:

[The 1949 Geneva Conventions and the Additional Protocol I] must be fully applied in all circumstances to all persons who are protected by those instruments, without any adverse distinction based on the nature or origin of the armed conflict or on the causes espoused by or attributed to the Parties to the conflict. ${ }^{125}$

This provision clearly bars jus ad bellum from thwarting jus in bello's application: 'The fact of being the aggressor or the victim of aggression, of espousing a just or an unjust cause, does not absolve anyone from his obligations nor deprive anyone of the guarantees laid down by humanitarian law.' ${ }^{\prime 26}$ Besides these treaty norms, the jurisprudence of national and

\footnotetext{
${ }^{120}$ As Peter Haggenmacher wrote, '[n]ow that the field of vision had been restricted, greater attention could be paid to the conduct of hostilities: [F] or owing to this indifference [to the causes of war], armed violence came to be seen first and foremost as a process to be regulated in itself, regardless of its causes, motives and ends'. See P. Haggenmacher, Grotius et la doctrine de la guerre juste (1983), 599, cited from R. Kolb, 'Origin of the Twin Terms Jus ad Bellum/Jus in Hello', (1997) 37 International Review of the Red Cross (1961-1997) 553, at 557.

${ }^{121}$ Kolb, ibid., at 558 .

${ }^{122}$ Ibid., 561 .

${ }^{123} 1949$ Convention for the Amelioration of the Condition of the Wounded and Sick in Armed Forces in the Field, 75 UNTS 31, Art. 1.

${ }^{124}$ ICRC, Commentary on the First Geneva Convention: Convention (I) for the Amelioration of the Condition of the Wounded and Sick in Armed Forces in the Field (2016), 61, para. 186. The ICRC commentary of 1952 on Common Article 1 more specifically denies the relevance of the just war argumentation to the application of IHL: 'Whether a war is "just" or "unjust", whether it is a war of aggression or of resistance to aggression, the protection and care due to the wounded and sick are in no way affected.' See J. S. Pictet (ed.), The Geneva Conventions of 12 August 1949: Commentary (1952), vol. I, at 27.

${ }^{125} 1977$ Protocol Additional to the Geneva Conventions of 12 August 1949, and relating to the Protection of Victims of International Armed Conflicts, 1125 UNTS 3, Preamble.

${ }^{126}$ B. Zimmermann, 'Protocol I - Preamble', in Y. Sandoz, C. Swinarski and B. Zimmermann (eds.), Commentary on the Additional Protocols of 8 June 1977 to the Geneva Conventions of 12 August 1949 (1987), 23, at 29, para. 32.
} 
international courts, by and large, follows and oftentimes explicitly refers to the ad bellum/in bello separation. ${ }^{127}$

It can be drawn from this historical trajectory of development that, despite its ostensible universal reach, the ad bellum/in bello separation sprang from the mutable European and Western conception of war which experienced the maturation of jus in bello in the European just war tradition, the advent of the positivist outlook of law and war with the decline of just war, and the emergence of the positive international legal rules regulating jus ad bellum and jus in bello in parallel. Joining the international community rather lately with no such cognitive transition, nonEuropean and non-Western states, while accepting the ad bellum/in bello separation as a valid legal arrangement, may not be supposed to invariably take it as culturally or ethically legitimate. This is the case for China which has constantly clung to a holistic understanding of the ad bellum/ in bello relationship. As Frédéric Mégret remarked:

[T] he very rigid separation of the jus in bello from the jus ad bellum - a process that took several centuries to be effected in the West, and that betrays a rather stark and characteristically modern distinction between the launching and the waging of war - may well be incompatible with more holistic approaches to war. ${ }^{128}$

\subsection{Shutting out 'just war': The western sensitivity behind the ad bellum/in bello separation}

Formed in the location where the ad bellum/in bello separation came into existence, the intellectual sensitivity behind this norm is even more reflective of its cultural imprint. IHL scholars upholding such separation commonly agree that it can be justified on two grounds. The first reason is a compelling humanitarian one. The discriminatory application of jus in bello (i.e., negating the rights of war victims affiliated with the belligerent which acts in violation of jus ad bellum) is intolerable today. Modern humanitarian philosophy claims that 'human suffering is human suffering, whether incurred in the course of a "just war" or not'. ${ }^{129}$ Internalizing this belief, IHL fully acknowledges that ' $[\mathrm{w}]$ ar victims need as much protection against the belligerent fighting in conformity with ius ad bellum as against a belligerent who violated ius contra bellum'. ${ }^{130}$ It is now considered definitely inhumane protecting the civilian population of the victim state of aggression from atrocities while conniving at some of them when they are committed against the people of the aggressor. As civilians, they are all presumed innocent irrespective of their affiliations. ${ }^{131}$

The second reason concerns the functioning of IHL on the battleground. It is a commonplace that an armed conflict is fought in the absence of an objective and authoritative pronouncement on the legality of the use of force. If IHL were to confer fewer rights on the side which violates jus

\footnotetext{
${ }^{127}$ For overviews of the case law affirming the ad bellum/in bello separation see Dinstein, supra note 93, at 171-2; H. Lauterpacht, 'The Limits of the Operation of the Law of War', (1953) 30 Brit. Y.B. Int'l L. 206, at 215-20; J. Moussa, 'Can Jus ad Bellum Override Jus in Bello? Reaffirming the Separation of the Two Bodies of Law', (2008) 90 IRRC 963, at 981-7; T. S. Harris, 'Can the ICC Consider Questions on Jus ad Bellum in a War Crimes Trial?', (2016) 48 Case W. Res. J. Int'l L. 273, at 299-301.

${ }^{128}$ Mégret, supra note 12 , at 683.

${ }^{129} \mathrm{G}$. Best, Humanity in Warfare: The Modern History of the International Law of Armed Conflicts (1983), 4.

${ }^{130} \mathrm{M}$. Sassòli, 'Ius ad Bellum and Ius in Bello - The Separation between the Legality of the Use of Force and Humanitarian Rules to Be Respected in Warfare: Crucial or Outdated?', in M. N. Schmitt and J. Pejic (eds.), International Law and Armed Conflict: Exploring the Faultlines: Essays in Honour of Yoram Dinstein (2007), 241, at 245. See also Bouvier, supra note 2, at 112; Moussa, supra note 127, at 967; R. Kolb and R. Hyde, An Introduction to the International Law of Armed Conflicts (2008), 25.

${ }^{131}$ Jeff McMahan noted, in moral terms, that "in the context of war, "innocent" is usually treated as synonymous with "civilian"'. See J. McMahan, 'Jus in Bello and Jus ad Bellum', (2006) 100 Proceedings of the Annual Meeting (ASIL) 112, at 113. Gabriella Blum also expounded that civilians 'are all presumed innocent unless proven threatening; this is why [according to IHL] civilians enjoy immunity unless and for such time that they take direct part in hostilities. In case of doubt, an individual must be presumed to be an innocent civilian'. See G. Blum, 'The Fog of Victory', (2013) 24 EJIL 391,417 (internal citations omitted); 1977 Protocol Additional to the Geneva Conventions of 12 August 1949, and relating to the Protection of Victims of International Armed Conflicts, 1125 UNTS 3, Arts. 50(1), 51(3).
} 
ad bellum, every belligerent would be tempted to, upon claiming itself as a victim of injustice, impress upon its foe some discrimination in the application of law while refusing to countenance any such discrimination against itself. ${ }^{132}$ This vicious circle of mutual demonization is bound to drag IHL to the verge of total collapse. Even when the issue concerning jus ad bellum is settled by a competent authority (which rarely occurs), the disadvantaged side would insubordinately reject the application of certain IHL norms inasmuch as no reciprocity is in sight. As Hersch Lauterpacht stressed, it is impossible to visualize the conduct of hostilities in which one side would be bound by rules of warfare without benefiting from them and the other side would benefit from rules of warfare without being bound by them'. ${ }^{133}$ Only when - as a result of the ad bellum/in bello separation - the same rules apply to both sides, is IHL able to take effect normally.

It is not difficult to discern the Western sensitivity to the European just war tradition behind both justifications. Mainstream scholars - who are simultaneously and not coincidentally Westerners clearly have in mind, when framing these justifications, the European model of just war as the repulsive antithesis of the ad bellum/in bello separation. ${ }^{134}$ As seen from Section 4.1, over a long period of time, European just war thinkers had analysed the nature of war and the rights of belligerents exclusively from the act of resorting to war, and more particularly on the cause pursued. ${ }^{135}$ Neither the Roman nor the theological theory, in construing the meaning of 'justice', attached even a little importance to the sporadic and scattered dicta on jus in bello. Jus in bello was once conditioned by jus ad bellum: 'The justness of the resort to war determined to a large extent the limits on the conduct of war ... [O]nce the cause was just, any means to achieve the end was permissible.'136

Perhaps to the dissatisfaction of many, this foundational mind-set chaining jus in bello to jus ad bellum not only survived the end of the Middle Ages but also had haunted the 'fathers' of international law who, through aggregated efforts, spoke against the cruelty of the old tradition. ${ }^{137}$ For example, both Grotius and Vattel wrote about moderation in war in the jus ad bellum sense of the word. ${ }^{138}$ When formulating the natural law norms of $j u s$ in bello, they both took the medieval tenet as a point of departure. Grotius's doctrine of jus in bello begins with the basic rule that where the punishment is just, whatever is a means necessary to execute that punishment is just. ${ }^{139}$ Vattel similarly conceded that the whole jus in bello in just war can be deduced from one single principle: ' $[\mathrm{W}]$ hen the end is lawful, he who has a right to pursue that end, has, of course, a right to employ all the means which are necessary for its attainment. ${ }^{140}$ Moreover, Grotius's proposal of moderation in war addressed only belligerents resorting to war for a just cause; the behaviour of those without such a cause was subject to no legal restraints. ${ }^{141}$ All acts of hostilities done by the latter were categorically treated as 'unjust in themselves'. ${ }^{142}$ Given such a deep-rooted natural law

\footnotetext{
${ }^{132} \mathrm{Kolb}$ and Hyde, supra note 130, at 24.

${ }^{133}$ Lauterpacht, supra note 127, at 212. See also Sassòli, Bouvier and Quintin, supra note 13, at 19; Kolb and Hyde, supra note 130, at 25; F. Bugnion, 'Guerre juste, guerre d'agression et droit international humanitaire', (2002) 84 IRRC 523, at 538; E. Benvenisti, 'Rethinking the Divide between Jus ad Bellum and Jus in Bello in Warfare against Nonstate Actors', (2009) 34 Yale J. Int'l L. 541, at 545 .

${ }^{134}$ Jasmine Moussa expressly made this point: 'The principle of separation of jus ad bellum and jus in bello, and its corollary the principle of "equal application" of IHL, can thus be said to be the antithesis of “just war" theory.' See J. Moussa, 'Nuclear Weapons and the Separation of Jus ad Bellum and Jus in Bello', in G. Nystuen, S. Casey-Maslen and A. G. Bersagel (eds.), Nuclear Weapons under International Law (2014), 59, at 66.

${ }^{135} \mathrm{Kolb}$, supra note 120 , at 554.

${ }^{136}$ J. G. Gardam, 'Proportionality and Force in International Law', (1993) 87 AJIL 391, at 395 (internal citations omitted).

${ }^{137} \mathrm{Neff}$, supra note 17 , at 91.

${ }^{138}$ Gardam, supra note 136, at 396. Indeed, as shown in Section 4.1, Vitoria, Grotius, and Vattel all first investigated the possibility for a war to be just on both sides before reasoning the importance of constraint on the conduct of war for mitigating harm to belligerents which could be both considered sinless.

${ }^{139}$ Grotius, supra note 110 , at 1187 .

${ }^{140} \mathrm{de}$ Vattel, supra note 112 , at 541-2.

${ }^{141} \mathrm{Kolb}$, supra note 120 , at 555.

${ }^{142}$ Grotius, supra note 110 , at 1416 .
} 
tradition of discrimination, it is understandable why Vattel, as noted in Section 4.1, merely identified the existence of the rule of the even-handed treatment of belligerents within the purview of the law of nations.

Such a pattern of moral assessments of war in the European tradition, in which jus in bello was parasitic on jus ad bellum, blatantly collides with IHL which seeks '- for humanitarian reasons - to protect persons who are not or are no longer directly participating in the hostilities, and to restrict means and methods of warfare'. ${ }^{143}$ As envisaged in the justifications for the ad bellum/in bello separation, if IHL were to be applied in conformity with the European just war paradigm, no humane and effective protection of war victims, at either end of the spectrum, can be sought. This consequence would, in turn, ruin the end-goal and credibility of IHL. It has, thus, become a common belief that the European just war theory is definitely answerable for the horror and brutality of European warfare in bygone days. As Jean Pictet wrote, it was 'the antique myth of the just war' that 'caused so much evil in the past'. ${ }^{144}$ Richard Baxter similarly alleged that 'the idea of the just war has in the past been productive of some of the worst offenses against the victims of war'. ${ }^{145}$ As a matter of fact, it was not until the idea of just war had lived out its long life and its usefulness that belligerents came to adopt more civilized usages in warfare. ${ }^{146}$ With too much innocent blood spilled in the name of justice, the repulsive concept of just war shall be shut out of IHL once and for all, and the autonomy of jus in bello seemed an inescapable path toward this end. As Anthony Coates noted, '[i]t is no coincidence that ideas about the independent application of jus in bello gained ground after the experience of wars of religion, fuelled to devastating effect by sectarian enthusiasm'. ${ }^{147}$ Propounded upon consequentialist instead of historical or logical grounds, both justifications for the ad bellum/in bello separation as given by IHL scholars, shedding light on the catastrophic consequences of just war - discriminatory treatment of war victims and, worse still, the collapse of jus in bello itself, intimate scholars' collective trauma from this monstrous intellectual creation.

While the ad bellum/in bello separation is duly integrated into treaty texts, its viability has come under threat from time to time. In the West's defence of this norm, malaise and anxiety have been expressed in relation to diverse attempts whose aims, as believed, are to reinstate the notion of just war in international law. The most intense and illustrative bout hitherto concerns the problem of wars of national liberation. Traditionally, anticolonial struggles were viewed as internal wars to which the law of international armed conflict was inapplicable. ${ }^{148}$ In the 1960s and 1970s, the socialist bloc and many of the newly independent states called upon the international community to recognize such wars as international ones to which IHL applies in its entirety. ${ }^{149}$ Obviously, the conceived legal consequence of 'upgrading' wars of national liberation was to equip the national liberation movements with a much broader variety of jus in bello rights which they did not possess in the past.

\footnotetext{
${ }^{143}$ ICRC, International Humanitarian Law: Answers to Your Questions (2014), 4.

${ }^{144}$ J. Pictet, Development and Principles of International Humanitarian Law (1985), 83.

${ }^{145}$ R. R. Baxter, 'Humanitarian Law or Humanitarian Politics?: The 1974 Diplomatic Conference on Humanitarian Law', (1975) 16 Harv. Int'l. L. J. 1, at 17.

${ }^{146}$ G. I. A. D. Draper, 'The Christian and War', (1962) 2 International Relations 378, 396.

${ }^{147}$ A. Coates, 'Is the Independent Application of Jus in Bello the Way to Limit War?', in D. Rodin and H. Shue (eds.), Just and Unjust Warriors: The Moral and Legal Status of Soldiers (2008), 176, at 179.

${ }^{148} \mathrm{G}$. Abi-Saab, 'Wars of National Liberation and the Laws of War', (1972) 3 Annales d'études internationals 93, at 94. Prior to the adoption of the Additional Protocol II of the 1949 Geneva Conventions in 1977, the international legal norms regulating non-international armed conflict were scarce. The only rule of the 1949 Geneva Conventions that is applicable to such conflict is Common Art. 3 which sets up merely basic standards to abide by. See 1949 Convention for the Amelioration of the Condition of the Wounded and Sick in Armed Forces in the Field, 75 UNTS 31, Art. 3.

${ }^{149}$ For instance, UN General Assembly Res. 3103, promoted by these states, proclaims that ' $\mathrm{t}$ ] he armed conflicts involving the struggle of peoples against colonial and alien domination and racist régimes are to be regarded as international armed conflicts in the sense of the 1949 Geneva Conventions'. See Basic Principles of the Legal Status of the Combatants Struggling against Colonial and Alien Domination and Racist Régimes, UN Doc. A/Res/3103 (XXVIII) (1973), para. 3.
} 
Such efforts culminated in the demand to validate, as a treaty rule, the international character of wars of national liberation, in the upcoming Additional Protocol I of the 1949 Geneva Conventions negotiated among states during 1974 and 1977. At the diplomatic conference, while the majority of the proponents of this programme, not interested in the ideological debate, treated it as simply a codification of international law in force, a small number of states grounded their demand based on the 'just war' words: it was asseverated to be absurd if the people fighting for just wars of national liberation could not benefit from the effective protection of IHL. ${ }^{150}$ It is fair to say that the latter group of states did not use the term 'just war' in the European sense which triggered asymmetric application of jus in bello in favour of the just belligerent. ${ }^{151}$ Instead, they were focused on asking the law to provide equal treatment by extending combatants' privilege and prisoner-of-war status to national liberation fighters. ${ }^{152}$ Nevertheless, such a modus operandi may still be taken as a variation on European just war in the sense that national liberation movements, claiming the justness of their cause under jus ad bellum, are placed in a better position under jus in bello than other rebel or insurgent groups. ${ }^{153}$

Caught off guard by the arrival of 'just war' at the conference hall, many Western delegations raised serious objections to the legitimacy of the perspective resurrection of this notorious concept in international law. The UK typically stated that '[just and unjust wars] were extremely dangerous approaches and totally alien to all the principles of [IHL]. They struck at the very heart of the Geneva Conventions and the philosophy of equality of rights and non-discrimination which inspired them'. ${ }^{154}$ Along the same line, the US explained that ' $t$ ] he introduction into [IHL] of "just war" concepts would inevitably result in a lowering of the standards of protection accorded to war victims'. ${ }^{155}$ Many other Western states, including the Holy See, ${ }^{156}$ Belgium, ${ }^{157}$ Switzerland, ${ }^{158}$ New Zealand, ${ }^{159}$ Australia, ${ }^{160}$ and three of the Nordic countries, ${ }^{161}$ all expressed their disapproval of debating over just war' during a treaty-making conference and of introducing, although in a disguised form, this concept into the IHL treaty rules.

In the same vein, Western scholars, when touching upon the subject of wars of national liberation, have tended to denounce the notion of just war as a serious hazard to the system of IHL. For instance, Michael Bothe and other two commentators averred that 'a distinction [between just and unjust wars] belonged to the ius ad bellum but not to the ius in bello and could under no

\footnotetext{
${ }^{150}$ A. Cassese, 'Current Trends in the Development of the Law of Armed Conflict', in A. Cassese, The Human Dimension of International Law: Selected Papers (2008), 7-8.

${ }^{151}$ Ibid., at 7.

${ }^{152}$ J. Whyte, "The "Dangerous Concept of the Just War": Decolonization, Wars of National Liberation, and the Additional Protocols to the Geneva Conventions', (2018) 9 Humanity: An International Journal of Human Rights, Humanitarianism, and Development 313 , at 323 .

${ }^{153}$ As David Forsythe commented, the concept of wars of national liberation 'was seen as creating a double standard. If the war was just, the law of international armed conflict applied, ipso facto. If the war was not just, the application of that law depended upon the geomilitary scale of the conflict'. See D. P. Forsythe, 'The 1974 Diplomatic Conference on Humanitarian Law: Some Observations', (1975) 69 AJIL 77, at 80.

${ }^{154}$ Official Records of the Diplomatic Conference on the Reaffirmation and Development of International Humanitarian Law Applicable in Armed Conflicts (Geneva, 1974-1977), vol. V, at 134, para. 37.

${ }^{155}$ Ibid., at 110 , para. 47.

${ }^{156}$ Ibid., at 123 , para. 34 .

${ }^{157}$ Ibid., at 114 , para. 68 .

${ }^{158}$ Ibid., at 137 , para. 53 .

${ }^{159}$ Ibid., at 180 , para. 39 .

${ }^{160}$ Official Records of the Diplomatic Conference on the Reaffirmation and Development of International Humanitarian Law Applicable in Armed Conflicts (Geneva, 1974-1977), vol. VIII, at 103, para. 44.

${ }^{161}$ Ibid., at 37, para. 22; Official Records of the Diplomatic Conference on the Reaffirmation and Development of International Humanitarian Law Applicable in Armed Conflicts (Geneva, 1974-1977), vol. V, at 142, para. 5; Official Records of the Diplomatic Conference on the Reaffirmation and Development of International Humanitarian Law Applicable in Armed Conflicts (Geneva, 1974-1977), vol. XIV, at 333, para. 71.
} 
circumstances find a place in humanitarian law'. ${ }^{162}$ Ingrid Detter similarly depicted 'obsolete theories of the just war' to be 'conceptually and practically unacceptable in these days' ${ }^{163}$ Witnessing its arguable rise in IHL, David Graham wrote that '[u]ntil the concept of "just war" is again recognized as an invalid rationale upon which to base death and destruction, no real progress in this area can be realized'. 164

Subsequent to the quarrel over wars of national liberation, more doctrinal variations on European just war emerged in later decades, including, in particular, self-defence in extreme circumstances, humanitarian intervention, the Security Council enforcement action and 'war on terror'. In the opinions of some, these notions are inherently just causes struggling against the grave and immoral evil, and hence justify certain measures going beyond the boundaries of IHL. ${ }^{165}$ Keeping a watchful eye on the ebb and flow of these intruders, mainstream scholars have delved into their legal implications, and refused to recognize as legitimate varied ways through which the causes of war are licensed to vitiate the equal application of IHL. ${ }^{166}$ Defending the ad bellum/in bello separation in IHL against the erosion of the disturbing recrudescence of 'just war' has hence been undertaken by Western scholars as a perennial mission to fulfil. Such inborn antagonism towards 'just war' may provide a cultural explanation to the initial enquiry on why challenges to the ad bellum/in bello separation have, as yet, proved largely fruitless.

\subsection{When East meets West: Different paradigms for framing the ad bellum/in bello relationship}

The ad bellum/in bello separation not only grew out of the evolution of the European and Western conception of war but also manifests evident Western sensitivity to the European just war tradition. In both the governmental and scholarly discourses of IHL in the contemporary West, the aversion to the concept of just war sticks out a mile. For the Chinese, however, the term 'just war', which immediately brings to mind mythical sage kings' glorious deeds of removing the oppressors and championing the law-abiding citizens, has never been deemed a disquieting or terrifying concept. Upon a comparison of the principal discrepancies between Chinese and European conceptions of just war, the cultural seeds buried underneath the ad bellum/in bello separation - the so-called antithesis of 'just war' - may be dug out.

As a point of departure, China and Europe differed fundamentally in perceiving the world order and the meaning of war within it. China, as a self-styled universal empire, once sincerely believed that it was morally entitled to govern every person and piece of land under heaven. Upon a formally hierarchical worldview, war was, and perhaps could only be, generally characterized as the most formidable form of punitive law enforcement exerted by superiors (mostly, the Chinese monarch) against inferiors. In Europe, national borders and identities were conceptually established and maintained. Even at the height of the Roman Empire's power, Europeans never thought, like the Chinese, that the Roman state literally embraced the entire world. ${ }^{167}$ Instead, in the Roman world accommodating the concept of jus gentium

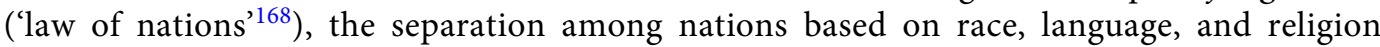

\footnotetext{
${ }^{162}$ M. Bothe, K. J. Partsch and W. A. Solf (eds.), New Rules for Victims of Armed Conflicts Commentary on the Two 1977 Protocols Additional to the Geneva Conventions of 1949 (2013), 39.

${ }^{163}$ I. Detter, The Law of War (2000), 101-2.

${ }^{164}$ D. E. Graham, 'The 1974 Diplomatic Conference on the Law of War: A Victory for Political Causes and a Return to the "Just War" Concept of the Eleventh Century", (1975) 32 Washington and Lee Law Review 25, at 63 (emphasis in original).

${ }^{165}$ Moussa, supra note 127 , at 964.

${ }^{166}$ For recapitulations of debates over those outgrowths of 'just war' see, e.g., ibid., at 968-74, 987-9; Sloane, supra note 118, at $80-103$.

${ }^{167}$ Neff, supra note 17 , at 33 .

${ }^{168}$ B. A. Garner (ed.), Black's Law Dictionary (2009), 939.
} 
clearly existed in idea and in reality. ${ }^{169}$ In this formally equal inter-state order, war had long been seen as conflict between nations or sovereigns competing against each other.

These fundamental discrepancies were determinative of the ad bellum/in bello relationship framed respectively in the Chinese and European just war traditions. First and foremost, Chinese and European traditions differed essentially in the observation point taken. In the Chinese context, just war, involving moral superiors punishing the villainous, was of a builtin vertical structure. As a law enforcement action of the sage kings for the sake of the harmony of the world, just war served the quality of the socio-political order as a whole rather than any particular interest group within it. ${ }^{170}$ That is to say, a harmonious outcome making the best of the circumstances was precisely what the Chinese (rulers) were interested in. ${ }^{171}$ Therefore, the Chinese just war theory was formulated with the ubiquitous emphases on the duties of the just belligerent under (and beyond) jus in bello for the well-being of the world, with insufficient attention paid to those of the unjust side which was simply the object of law enforcement. Central to this top-down approach was that, as illustrated in Section 3.1, a just war should be conducted in a just manner. In the European tradition, war, whether just or not, resembled a duel between horizontal conflicting groups of peoples. Europeans, identifying themselves more strongly with their individual states than with Christendom as a whole, concerned more with their own national honour than achieving the best outcome for all parties. ${ }^{172}$ There was even a common belief that one state's safety during war depended on the elimination of those possessing a different nationality. ${ }^{173}$ As a result, the European just war theory was concentrated on elaborating upon the rights of the just belligerent under jus in bello, with the synchronous denial of those of the unjust side. The basic logic was that a just war should be conducted for the benefit of the just side and to the detriment of its unjust opponent. ${ }^{174}$

Secondly, Chinese and European traditions were in disagreement as to who should be treated as enemies for the purpose of just war. The Chinese, conceiving no multi-national relations, believed that every person was a nominal subject of the universal king in China. National sentiment in its modern meaning was absent in pre-modern China. ${ }^{175}$ Even the most savage barbarians were not considered aliens but simply uncivilized and outlandish peoples awaiting assimilation into the Chinese cultural orbit. ${ }^{176}$ Therefore, just war should be fought on behalf of the populations on both sides. ${ }^{177}$ In this sense, as discussed in Section 3.1, a just belligerent should only treat those who were responsible for atrocities, brutalities and chaos, rather than the population of the targeted state, as enemies. Europeans, on the other hand, embraced a clear differentiation between 'us' and 'others' when going to wars. Western theorists commonly agreed that when a war was proclaimed against a nation, it was also proclaimed against all subjects of that nation. ${ }^{178}$ All subjects of that nation, including women

\footnotetext{
${ }^{169}$ C. P. Fitzgerald, The Chinese View of Their Place in the World (1964), 15.

${ }^{170}$ R. T. Ames, 'Preface to the Ballantine Edition', in Sun-Tzu the Art of Warfare: The First English Translation Incorporating the Recently Discovered Yin-Ch'Üeh-Shan Texts (1993) (translated by R. T. Ames), 9, at 49.

${ }^{171}$ K. Hagen, 'A Chinese Critique on Western Ways of Warfare', (1996) 6 Asian Philosophy 207, at 214.

${ }^{172}$ Ibid.

${ }^{173}$ Adelman and Shih, supra note 44 , at 23.

${ }^{174}$ G. I. A. D. Draper, 'Wars of National Liberation and War Criminality', in M. Howard (ed.), Restraints on War: Studies in the Limitation of Armed Conflict (1979), 135, at 158. It was further alleged that 'the violences, the crimes, the disorders of every kind, attendant on the tumult and licentiousness of war' were all imputable to the unjust belligerent (which was accused as 'the original author of them all'). See de Vattel, supra note 112, at 483.

${ }^{175} \mathrm{Li}$, supra note 33 , at 29 . It was only when the Chinese first began studying international law in the second half the nineteen century that they understood the implications of sovereignty, and it was this realization that rapidly fostered Chinese nationalism. See J. Pan, 'Sovereignty's Implications for China: Then and Now', in P. Sevastik (ed.), Aspects of Sovereignty: SinoSwedish Reflections (2013), 15, at 17.

${ }^{176} \mathrm{Hsü}$, supra note 34 , at 7 .

${ }^{177}$ Hagen, supra note 171, at 214.

${ }^{178}$ Grotius, supra note 110 , at 1281 ; de Vattel, supra note 112 , at 509.
} 
and children, were ranked in the class of enemies. ${ }^{179}$ Just war was, in effect, an all-out struggle to insure the prevalence of righteousness. ${ }^{180}$

As a corollary of the different approaches to identifying enemies, the nature of non-combatant immunity - a cardinal issue of jus in bello - was weighed differently in two traditions. In the Chinese tradition, since enemies were narrowly defined, for a war to be just, a self-evident, although rough, principle of distinction between the guilty and the innocent had to be always kept in mind. As Xunzi indicated, '[a]s a general principle, in punitive expeditions, punishment is not extended to the [populace], but rather only to those who have caused anarchy among them'. ${ }^{181}$ Non-combatant immunity, which first appeared in number in Chinese classics written two and a half millennia ago, was ingrained into the concept of just war. While the European tradition also upheld the idea of non-combatant immunity at a later stage, it failed to exempt non-combatants of an enemy nation from being labelled as enemies. Vattel, for example, explained clearly that the reason for sparing certain categories of persons lay in their status as 'enemies who make no resistance'. ${ }^{182}$ A result of such taxonomy was that the European tradition did not firmly regard non-combatant immunity as an ingredient of justice. It was no coincidence that when pleading for sparing those who did not fight, Grotius, in the meantime, murmured that such self-restraint was proposed for mercy, 'if not for [j] ustice'. ${ }^{183}$

Given these distinct divergences in conceptualizing enemy identity and non-combatant immunity, the concrete means and methods of warfare under jus in bello enjoyed significantly different degrees of moral acceptability in the two traditions. An impression that dominated the European tradition for long was that once arms were taken up in the name of justice, all the noble and chivalric thoughts might be set aside. ${ }^{184}$ The most drastic example is the theological notion of 'holy war', which once prevailed in Medieval Europe and was often invoked to justify annihilating completely an enemy state and slaughtering its people. The Old Testament contains the following precepts:

And when the Lord thy God hath delivered it into thine hands, thou shalt smite every male thereof with the edge of the sword:

But of the cities of these people, which the Lord thy God doth give thee for an inheritance, thou shalt save alive nothing that breatheth:

But thou shalt utterly destroy them . . . as the Lord thy God hath commanded thee: ${ }^{185}$

Such a fearsome idea, abused by religious fanaticism, can hardly be found in Chinese records, just as an avenging God and the wrath of Jehovah are far to seek. ${ }^{186}$ In contrast, Chinese military leaders who sincerely wished to be the incarnation of justice rarely contemplated wars aimed at conquest of enemy territories, total destruction of the enemy, or massacring the civilians of an enemy state. ${ }^{187}$ There should be a self-conscious effort, prompted by the sense of righteousness, not to

${ }^{179} \mathrm{de}$ Vattel, ibid., at 510. As Hans Morgenthau illustrated, '[i]n those times war was considered a contest between all the inhabitants of the territories of the belligerent states ... Thus ever individual citizen of the enemy state became an enemy of every individual citizen of the other side'. See H. J. Morgenthau, Politics among Nations: The Struggle for Power and Peace (1948), 178.

${ }^{180}$ Hagen, supra note 171 , at 211.

${ }^{181}$ Knoblock, supra note 37, at 227, para. 15.1f. See also Zhu, supra note 64, at 269.

${ }^{182} \mathrm{de}$ Vattel, supra note 112, at 549 (emphasis added).

${ }^{183}$ Grotius, supra note 110 , at 1439 .

${ }^{184}$ Hagen, supra note 171 , at 211.

${ }^{185}$ The Old Testament (2013), 285 (emphasis omitted).

${ }^{186}$ Fairbank, supra note 44 , at 7 . The Chinese lacked religious passion. As the only major religion in China (if Confucianism did not count as a religion), Buddhism happened to be very pacifistic. See S. Hu, 'Revisiting Chinese Pacifism', (2006) 32 Asian Affairs: An American Review 256, at 262.

${ }^{187}$ Y. Wang, Harmony and War: Confucian Culture and Chinese Power Politics (2011), 19. 
spread the violence and savagery to the common people. ${ }^{188}$ As Karen Turner observed, ' $\mathrm{t}$ ] he argument that force must be limited by rules designed to protect the innocent victims of war differentiates the Chinese theory of righteous war from traditional Western just war theory'. ${ }^{189}$

Another noteworthy example reflecting the different mentality of the Chinese and Europeans is the moral justifiability of criminal offences committed under the banner of justice. In the Chinese tradition, most criminal and immoral acts remained inexcusable even if they were conducted during just war: even for soldiers of a just belligerent, '[w] hoever kills people's fathers and elder brothers; whoever profits himself with the riches and goods of other men; whoever makes slaves of the sons and daughters of other men is in all cases a brigand'. ${ }^{190}$ On the contrary, in the teleological just war theory of Europe, acts that would otherwise be deemed criminal - such as brigandage and robbery - could be rendered legitimate and defensible when they were conducted by 'just warriors'. ${ }^{191}$ For instance, shortly after Friedrich I of the Holy Roman Empire ordered his troops to 'ruthlessly and ferociously' slaughter more than a thousand Roman citizens in 1155, Pope Hadrian celebrated mass for those soldiers and absolved them any sins, on the grounds that they, warring justly against enemies of the Church, were not murderers but avengers. ${ }^{192}$

To sum up, compared with its European counterpart, the Chinese tradition measured in a more balanced manner the weight of jus ad bellum and jus in bello as two facets of just war: The latter considerations remained persistently an element of just war and often overrode the former in evaluating the justness of war. Such a crucial disparity between the Chinese and European theories resulted in two contrasting historical paradigms for framing the ad bellum/in bello relationship: While the Chinese revered the benign interplay between jus in bello and jus ad bellum by urging a belligerent to sanctify or vindicate the justness of its campaign by behaving itself, Europeans stroke hard on the negative side of such interaction by permitting a belligerent to invoke a just cause to annul the rights of its 'evil' foe.

With the European just war theory in mind only, Western scholars widely assume that the communication between jus ad bellum and jus in bello would bring nothing but the subordination of jus in bello to jus ad bellum which undermines the restraint of war ${ }^{193}$ - an outcome stands starkly at odds with the humanitarian spirit that prevails in our days. In their subconsciousness, jus ad bellum and jus in bello are not only distinct but also conceptually in conflict with one another: The former empowers belligerents whereas the latter restrains them. ${ }^{194}$ In other words, the ad bellum/in bello relationship is understood to be adversarial, in which one is promoted at the expense of the other. ${ }^{195}$ Therefore, to obviate such a collision between them and, consequently, the unacceptable total destruction of IHL, jus ad bellum and jus in bello must be doggedly kept separate.

Evidently, the adversarial relationship between jus ad bellum and jus in bello and the resultant separation between the two make full sense in consideration of the European just war paradigm. In the Chinese paradigm, the relationship between the two bodies of norms is nevertheless a harmonious one: Jus ad bellum assimilates jus in bello but does not ruin it, and jus in bello tames jus ad bellum but does not devalue it. They are like the yin and yang of just war: Being interconnected

\footnotetext{
${ }^{188}$ P. Lo, 'How Virtues Provide Action Guidance: Confucian Military Virtues at Work', in S. C. Angle and M. Slote (eds.), Virtue Ethics and Confucianism (2013), 141, at 150.

${ }^{189}$ K. Turner, 'War, Punishment, and the Law of Nature in Early Chinese Concepts of the State', (1993) 53 Harvard J. Asiat. Stud. 285, 304.

${ }^{190}$ 'Wei Liao-tzu', in Sawyer, supra note 43, at 254.

${ }^{191}$ G. I. A. D. Draper, 'Grotius' Place in the Development of Legal Ideas about War', in H. Bull, B. Kingsbury and A. Roberts (eds.), Hugo Grotius and International Relations (1990), 177, at 182; M. H. Keen, The Laws of War in the Late Middle Ages (2016), 65.

${ }^{192}$ B. J. Verkamp, 'Moral Treatment of Returning Warriors in the Early Middle Ages', (1988) 16 Journal of Religious Ethics 223, at 230-1.

${ }^{193}$ Coates, supra note 147 , at 177.

${ }^{194}$ Ibid., 180.

${ }^{195}$ Sharma, supra note 4 , at 23.
} 
and interdependent with one another, they form an integral whole at the service of campaigns for pacifying the world. Since implementation of humanitarian values is entrusted to the belligerents with just causes, the Chinese can hardly be aware of any moral need for the ad bellum/in bello separation.

\section{The path towards a constructive ad bellum/in bello relationship}

The issue of the relationship between jus ad bellum and jus in bello has stirred up heated academic debates in both law and ethics. While the proponents of the ad bellum/in bello separation in IHL elevated this norm to the height of 'a bedrock principle', ${ }^{196}$ an 'absolute dogma', ${ }^{197}$ 'a fundamental [IHL tenet] beyond dispute', ${ }^{198}$ and even 'one of the oldest and best established axiomata of international law', ${ }^{199}$ generalized criticisms have arisen now and then inside the legal community. Firstly, the legal maxim ex injuria jus non oritur was said to forbid a guilty belligerent from benefiting from its illegal conduct. ${ }^{200}$ Upon this principle, 'some of the law of war is applicable to all states engaged in hostilities ... but that some of the advantages of this law are denied to aggressors' ${ }^{201}$ Secondly, states in practice do not often act scrupulously in conformity with the ad bellum/in bello separation which permits IHL to treat an aggressor and its victim on an equal footing. ${ }^{202}$ In reality, jus ad bellum still has a subtle impact on jus in bello. ${ }^{203}$ In terms of state practice, one clear and explicit objection to the ad bellum/in bello separation was raised by North Vietnam during the negotiation of the additional protocols to the 1949 Geneva Conventions. The North Vietnamese deplored the ad bellum/in bello separation as 'a flagrant anomaly' in light of the contemporary reality that 'the war of aggression is deemed to be "the ultimate international crime"'. ${ }^{204}$ They insisted that the equality between just and unjust belligerents before IHL, deduced from the ad bellum/in bello separation, should be 'condemned not only by modern positive law but also by logic, intelligence and morality'. ${ }^{205}$

It is telling that those dissenting views, like those defending the ad bellum/in bello separation, likewise fail to jump outside the box of European just war which openly discriminated the unjust belligerent. Consequently, only a pair of mutually exclusive options has been put on the table: either maintaining the ad bellum/in bello separation or, as the 'sole alternative', moving backwards, at least in part, into the antique shadow of European just war. In effect, since the European just war tradition has been habitually taken as the antithesis of the ad bellum/in bello separation, the degradation of this dialogue into such a black-or-white debate should not be surprising. What is nevertheless fatal is that such a preconception hampers scholars from thinking about a third approach to the ad bellum/in bello relationship - a more constructive solution beyond sealed separation. ${ }^{206}$

\footnotetext{
${ }^{196}$ Prosecutor v. Moinina Fofana, Allieu Kondewa, Judgement, Case No. SCSL-04-14-A, A.Ch., 28 May 2008 , para. 531.

${ }^{197}$ L. Doswald-Beck, 'International Humanitarian Law and the Advisory Opinion of the International Court of Justice on the Legality of the Threat or Use of Nuclear Weapons', (1997) 37 IRRC 35, at 53.

${ }^{198}$ G. S. Corn, 'Self-defense Targeting: Blurring the Line between the Jus ad Bellum and the Jus in Bello', (2012) 88 Int'l L. Stud. 57, at 65 .

${ }^{199}$ T. Gill, 'The Nuclear Weapons Advisory Opinion of the International Court of Justice and the Fundamental Distinction between the Jus ad Bellum and the Jus in Bello', (1999) 12 LJIL 613, at 614.

${ }^{200}$ Lauterpacht, supra note 127 , at 212.

${ }^{201} \mathrm{Q}$. Wright, 'The Outlawry of War and the Law of War', (1953) 47 AJIL 365, at 374. See also 'Draft Convention on Rights and Duties of States in case of Aggression', (1939) 33 AJIL 827, at 828.

${ }^{202}$ A. Orakhelashvili, 'Overlap and Convergence: The Interaction between Jus ad Bellum and Jus in Bello', (2007) 12 Journal of Conflict \& Security Law 157, at 196.

${ }^{203}$ Gardam, supra note 136 , at 393.

${ }^{204}$ Official Records of the Diplomatic Conference on the Reaffirmation and Development of International Humanitarian Law Applicable in Armed Conflicts (Geneva, 1974-1977), vol. IV, at 177.

${ }^{205}$ Official Records of the Diplomatic Conference on the Reaffirmation and Development of International Humanitarian Law Applicable in Armed Conflicts (Geneva, 1974-1977), vol. XIV, at 131, para. 21.

${ }^{206} \mathrm{~F}$. Mégret, 'Jus in Bello and Jus ad Bellum', (2006) 100 Proceedings of the Annual Meeting (ASIL) 121, at 122.
} 
It may be high time to rethink the unwarranted assumption, which came as a side effect of the European just war tradition, that jus ad bellum and jus in bello are irreconcilably in conflict and once they come into contact with each other, the former plays the devil with the latter. As explained on the basis of the Chinese tradition, the two bodies of norms may sit side by side harmoniously within one ethical system. This dynamic mind shift also appeals for breaking away from the stereotype that the European model of just war was the only alternative of the ad bellum/in bello separation. The case of Chinese just war shows that the unilateral and voluntary application of jus in bello can be projected as a moral duty of a belligerent which is eager to prove its justness under jus ad bellum; refusing to undertake such a duty leads to the forfeiture of its moral standing. It is not jus in bello that depends on jus ad bellum, but just the reverse.

These suggestions, however, do not mean that the ad bellum/in bello separation in IHL should be abrogated in toto. Given the fact that most self-professed just belligerents nowadays are still unwilling to accept that they have the same obligations and (only) the same rights as their unjust enemies, ${ }^{207}$ the principle that jus ad bellum does not impose restrictions on the application of jus in bello remains the last ditch of IHL to survive (as enshrined in the 1949 Geneva Conventions and their first Additional Protocol). But the constructive part of the ad bellum/in bello communication - the use of force undeniably triggering the application of IHL and disregard with IHL negating the legality of the use of force - may be recognized and implemented through proper legal mechanisms.

In the discourse of Western military ethics, this idea of subordinating jus ad bellum to jus in bello is not brand-new. ${ }^{208}$ Some contemporary Western just war theorists have already voiced their support for the formal recognition of jus in bello as a determinant of the nature of war, or at least as a touchstone for the 'right intention' which pertains to the jus ad bellum category. ${ }^{209}$ Be that as it may, as mentioned in Section 1, the strict ad bellum/in bello separation is being endorsed by the mainstream. In effect, in default of abundant historical illustrations drawn from the European tradition, it is doubtful whether such an ethical transformation could proceed swiftly and smoothly. More importantly, philosophers commonly lack interest in elaborating on the perspective implications of their propositions on the future of international law, thereby leaving this question largely underexplored.

As an international law scholar, Frédéric Mégret ventured some thoughts on a constructive ad bellum/in bello relationship. As he asked:

The problem with mixing jus ad bellum and jus in bello is typically that states will want to invoke the legitimacy of their cause to endorse fewer jus in bello obligations. But what if the peculiar nature of one's cause under the jus ad bellum meant that one should endorse slightly more rather than fewer jus in bello obligations? ${ }^{210}$

To be precise, this constructive relationship would mean first, that the disregard of jus in bello 'could invalidate an otherwise good cause, or at least make us think twice about whether that cause was good in the first place'; ${ }^{211}$ and second, that the belligerent with a justifiable cause 'should abide

\footnotetext{
${ }^{207}$ Sassòli, supra note 130, at 257.

${ }^{208}$ As Ping-cheung Lo observed, the emphasis of the Western just war theory has been shifted from jus ad bellum (legitimation) to jus in bello (restriction). See Lo, supra note 77, at 434.

${ }^{209}$ See, e.g., Bellamy, supra note 102, at 129; W. V. O’Brien, The Conduct of Just and Limited War (1981), 35; D. Rodin, 'The Ethics of Asymmetric War', in R. Sorabji and D. Rodin (eds.), The Ethics of War: Shared Problems in Different Traditions (2006), 153, at 160; I. Shearer, 'A Revival of the Just War Theory?', in M. N. Schmitt and J. Pejic (eds.), International Law and Armed Conflict: Exploring the Faultlines: Essays in Honour of Yoram Dinstein (2007), 1, at 1; L. May, Aggression and Crimes against Peace (2008), 114; S. P. Lee, Ethics and War: An Introduction (2012), 84.

${ }^{210}$ Mégret, supra note 206, at 122 (emphasis in original).

${ }^{211}$ Ibid., at 123. See also I. Österdahl, 'Dangerous Liaison? The Disappearing Dichotomy between Jus ad Bellum and in Bello', (2010) 78 Nordic J. Inter'l L. 553, at 559.
} 
by even higher standards of care, and either stay very much on the safe side of the law or even commit themselves unilaterally to a higher standard of care'. ${ }^{212}$

Put another way, the first legal implication of the proposed constructive ad bellum/in bello relationship would be judging the legality of the use of force through the lens of the conduct during warfare. Arguably, such a principle has been embraced to a limited extent in the jurisprudence of the International Court of Justice. In the Nuclear Weapons advisory opinion of 1996, the ICJ ruled that:

[A] use of force that is proportionate under the law of self-defence, must, in order to be lawful, also meet the requirements of the law applicable in armed conflict which comprise in particular the principles and rules of humanitarian law. ${ }^{213}$

This dictum echoes Christopher Greenwood's observation made decades ago: '[I]t is difficult to see how any use of force which violates the humanitarian rules of ius in bello ... can be regarded as reasonable measures of self-defence. ${ }^{214}$ In the Oil Platforms case of 2003, the ICJ followed this dictum by stating that in order to establish that it was legally justified in attacking the Iranian platforms in exercise of the right of individual self-defence, the [US] has to show that ... the platforms were a legitimate military target open to attack ... ${ }^{215}$ According to James Green, ' $[\mathrm{b}] \mathrm{y}$ indicting a requirement that a target must be of a military nature before it can be legitimately attacked in self-defence, the Court appears to have incorporated an element of [jus in bello] into the norms of [jus ad bellum]'. ${ }^{216}$

The second legal implication of the proposal is to invite the belligerent which claims itself as just to implement strictly its existing IHL obligations, and in addition to that, to accept, on a unilateral and voluntary basis, more beyond the relatively static international legal framework. Under the direct influence of the Chinese just war tradition, contemporary Chinese practice of IHL is probably illustrative of how these two suggestions may be materialized in state practice. On one hand, as several commentators testified, China, instead of paying lip service, did attach great importance to its IHL obligations. For example, Jamieson Greer, an army lieutenant of the US, drew the following conclusions upon reviewing China's belligerent behaviour in selected post-1949 international armed conflicts: first, the intuition of demonizing China as a capricious IHL violator is 'simplistic and dangerously incorrect'; second, China's violations of IHL norms are exceptions rather than the rule; and third, China adhered to IHL, participated in its development, and encouraged its application. ${ }^{217}$ In peacekeeping operations in which China has taken a part, 'Chinese personnel have a reputation for tight discipline and have not been tarnished by the sex and corruption scandals that have afflicted peacekeepers from some other nations'. ${ }^{218}$ On the other hand, China has voluntarily adopted domestic laws and regulations on constraints of its armed forces' behaviour. For instance, 'Three Main Rules of Discipline and the Eight Points for Attention', which are part of the Chinese law, ${ }^{219}$ contain rules like 'speaking politely', 'return everything you borrow', 'do

\footnotetext{
${ }^{212}$ Mégret, supra note 206, at 122.

${ }^{213}$ Legality of the Threat or Use of Nuclear Weapons, Advisory Opinion of 8 July 1996, [1996] ICJ Rep. 226, at 245, para. 42.

${ }^{214}$ C. Greenwood, 'The Relationship between Ius ad Bellum and Ius in Bello', (1983) 9 Review of International Studies 221 , at 227.

${ }^{215}$ Oil Platforms (Islamic Republic of Iran v. United States of America), Merits, Judgment of 6 November 2003, [2003] ICJ Rep. 161, at 186-7, para. 51.

${ }^{216} J$. A. Green, 'The Oil Platforms Case: An Error in Judgment?', (2004) 9 Journal of Conflict \& Security Law 357, at 380.

${ }^{217}$ J. L. Greer, 'China and the Laws of War: Patterns of Compliance and Disregard', (2006) 46 Va. J. Int'l L. 717, at 718-19, 741-2.

${ }^{218}$ A. Higgins, 'China Taking on Growing Role in U.N. Peacekeeping Missions', The Washington Post, 2 December $2009,8$.

${ }^{219}$ See 中国人民解放军纪律条令 [Discipline Regulations of the Chinese People's Liberation Army] (trial implementation, last amended 22 March 2018), Art. 5 and Ann. 1.
} 
not hit or swear at people', and 'do not take liberties with women'. ${ }^{20}$ Cognate with the rules made by ancient Confucian generals, ${ }^{221}$ these rules are a concise formulation of legalized moral duties that a righteous army is expected to bear. They are self-imposed, in addition to the country's obligations under IHL treaties which it has ratified and customary norms by which it is bound. Reciprocity is not a prerequisite for their implementation.

Due to the repugnance for 'just war', the presupposition on the ad bellum/in bello clash, and the resultant obsession in safeguarding their separation, mainstream IHL scholars tend to be sceptical about any suggestion of reviewing the norm of the ad bellum/in bello separation. The proposal of benign interaction between the two, however, is probably acceptable even for most rigid dogmatists of IHL. It would not undermine the equal application of IHL as a baseline, and could justify the indispensability of IHL, promote compliance with IHL, and enhance IHL's protective standards for war victims - implications that tally well with the rationale behind the ad bellum/in bello separation in IHL as displayed in Section 4.2. Moreover, listing respect for IHL as an additional criterion for the legality of the use of force would make potential war-makers less willing to initiate a war, as justifying a war could become a much more onerous task. ${ }^{222}$ For jus ad bellum to evolve into fully-fledged jus contra bellum, ${ }^{223}$ this reconnection of jus ad bellum and jus in bello in a constructive manner may be a meaningful step to take.

\section{Concluding remarks}

This article examines Chinese perspectives on the relationship between jus ad bellum and jus in bello, and offers a cultural critique of the ad bellum/in bello separation as embedded in IHL. In Chinese military ethics, it is jus ad bellum that depends on jus in bello. The ad bellum/in bello relationship has been construed as essentially holistic and harmonized. The cardinal moral principle underpinning it is that a just war should be conducted in a just way. In contrast, the European just war tradition had long subordinated jus in bello to jus ad bellum, and in this system, the two concepts were considered in conflict with each other. In the European and Western cultural context, the ad bellum/in bello separation has been adopted and meticulously maintained as an infrastructural norm of IHL, marking scholars' trauma from and aversion to the distasteful European just war tradition. Chinese perspectives nevertheless evidence that this conventional European and Western mode of thinking may have narrowed scholars' mind in seeking a more constructive ad bellum/in bello relationship. The proposal for subordinating the use of force to IHL and urging the would-be just belligerents to well behave themselves should draw academic attention.

Modern international law, of which IHL is a part, was a product of European states at its inception. Although it is beyond question that this Western-originated legal system has been highly successful in obtaining acknowledgement worldwide, international law has also been criticized as presenting a false appearance of preferences of dominated traditions and approaches which

\footnotetext{
${ }^{220}$ For the full text of 'The Three Main Rules of Discipline and the Eight Points for Attention' see M. Sassòli, A. A. Bouvier and A. Quintin (eds.), How does Law Protect in War?: Cases, Documents and Teaching Materials on Contemporary Practice in International Humanitarian Law (2011), vol. II, Case No. 106.

${ }^{221}$ For instance, Yangming Wang, an eminent Chinese philosopher and general in the early sixteenth century, laid down a set of rules aimed at training up a morally responsible army respectful of civilians and their property, including 'do not touch even a piece of grass or a tree without proper authorization', 'do not cheat or theft in making purchases in the marketplace', and 'do not cause disturbances to the local civilian inhabitants'. See S. B. Twiss and J. K. L. Chan, 'Wang Yang-ming's Ethics of War', in Lo and Twiss, supra note 49, 153, at 164.

${ }^{222}$ Österdahl, supra note 211 , at 565.

${ }^{223}$ In the era of the UN Charter which to a large extent limits the right of states to resort to force, jus ad bellum has shifted to a remarkable extent: Permission has been transformed into prohibition. Where it previously recognized an unlimited right to resort to force, it today requires states not to use force unless some narrowly defined exceptions are met. Thus, it may be said that jus ad bellum is evolving into a regime of jus contra bellum which literally means the law against war. See Kolb and Hyde, supra note 130 , at 13 .
} 
can make themselves appear as, or allows themselves to be, universal. ${ }^{224}$ While international lawyers often refrain from emphasizing local, regional, or national approaches to international law which seem to undermine the internationalist spirit of the profession, ${ }^{225}$ these matters cannot be neglected at will, as what has been fixed in the extant legal texts with the cultural patrimony lurking beneath may not always be the best way to ponder over an issue. As Jean d'Aspremont warned, ' $[w]$ hen one inhabits the centre, everything around looks universal ... Inhabiting the centre transforms our cognitive aptitude and makes us blind'. ${ }^{226}$ This caveat, although a bit harsh, may be an incisive presentation of the leitmotif of the cultural critique done in this article.

Whilst a broad historical brush depicts all societies as having had some sort of notion of restraint in warfare, it is also clear that they did not emphasize the same ideas or adopt the same institutions. ${ }^{227}$ Even under the extremely wide ratification of the 1949 Geneva Conventions, the cultural diversity in understanding, interpreting, and applying concrete IHL norms may not be ignored. ${ }^{228}$ Among all the issues that signal the Western cultural imprint on IHL, the ad bellum/in bello separation may merely be a tip of the iceberg. Comprehending the diverse states' and cultures' ways of interpreting the rules and approaching the philosophy of IHL can be thoughtprovoking for their future betterment, and be useful for tackling the daily challenges to this legal regime safeguarding the dignity and well-being of victims in the cauldron of war.

\footnotetext{
${ }^{224}$ A. Roberts, Is International Law International? (2017), 3.

${ }^{225}$ Koskenniemi, supra note 8 , at 3 .

${ }^{226}$ J. d'Aspremont, 'International Law, Universality, and the Dream of Disrupting from the Centre', (2018) 7 ESIL Reflections 1 , at 4 . See also Koskenniemi, supra note 8 , at 1.

${ }^{227}$ Mégret, supra note 12, at 683.

${ }^{228}$ For a critical reflection on the cultural diversity debate over IHL see R. Provost, 'The International Committee of the Red Widget? The Diversity Debate and International Humanitarian Law’, (2007) 40 Israel Law Review 614.
}

Cite this article: Liang Z (2021). Chinese perspectives on the ad bellum/in bello relationship and a cultural critique of the ad bellum/in bello separation in international humanitarian law. Leiden Journal of International Law 34, 291-320. https://doi.org/ 10.1017/S0922156521000054 